\title{
Genetic Determinants and Biochemical Correlates of Slow Coronary Flow: A Systematic Review and Meta-analysis
}

\author{
Himanshu Rai ${ }^{*}$ and Nakul Sinha ${ }^{2}$ \\ ${ }^{1}$ Department of Cardiology, Sanjay Gandhi Post Graduate Institute of Medical Sciences, Raebareli Road, Lucknow, Uttar Pradesh, India; \\ ${ }^{2}$ Department of Cardiology, Sahara India Medical Institute, Gomti Nagar, Lucknow, Uttar Pradesh, India
}

\begin{abstract}
Introduction: Slow coronary flow (SCF) is an angiographically observed phenomenon that is characterized by slow antegrade progression of radio-opaque contrast agent in the epicardial arteries and without any evidence of obstructive coronary artery disease. Published reports suggest that apart from having several established clinical and physical etiological factors, SCF might have some genetic determinants, along with some easily detectible biochemical correlates.
\end{abstract}

Materials and methods: We set out to consolidate the information from all published articles exploring genetic determinants, specifically, single nucleotide polymorphisms (SNPs), and/or biochemical correlates of SCF, employing a systematic review and possibly a meta-analysis.

Results: After a rigorous, well-defined, online database search, we identified 25 relevant original articles published up to December 2016. These articles reported on a total of 60 studies, including 14 for genetic determinants $\left(n_{s t}=14\right)$ and 46 for biochemical correlates of SCF $\left(n_{s t}=46\right)$. The present meta-analysis evaluating genetic determinants indicated statistically significant associations of two SNPs with SCF: nitric oxide synthase 3 (NOS3) gene variations of $-849 \mathrm{G}>\mathrm{T}$ ( $\mathrm{rs} 1799983$ ) and the $4 \mathrm{~b} / \mathrm{a} 27$ base pair (bp) variable number tandem repeat (VNTR). Both of these SNPs provide dominant as well as allelic genetic models. For rs1799983 $\left(\mathrm{n}_{\mathrm{st}}=2\right)$, the odds ratio (OR) range was 2.11-2.71, with a $Z$ value range of 2.91-3.00 and a $p$-value range of $0.003-0.004$.

Keywords: Meta-analysis; Genetic polymorphism; Systematic review; Slow coronary flow; Biochemical correlates.

Abbreviations: SCF, slow coronary flow; SNP, single nucleotide polymorphism; $N O S 3$, nitric oxide synthase 3; bp, base pair; VNTR, variable number of tandem repeats; CAD, coronary artery disease; TIMI-FC, thrombolysis in myocardial infarction-frame count; LAD, left anterior descending; LCX, left circumflex; RCA, right coronary artery; FMD, flow-mediated dilatation; PRISMA, preferred reporting items for systematic reviews and meta-analyses; HWE, Hardy-Weinberg equilibrium; $A C E$, angiotensin-converting enzyme; IL-10, interleukin-10; MTHFR, methylene tetrahydrofolate reductase; ICAM-1, intercellular adhesion molecule-1; $A G T$, angiotensinogen; PAI-1, plasminogen activator inhibitor-1; AGTRl, angiotensin II receptor type 1, NO, nitric oxide; Hcy, homocysteine; ET-1, endothelin-1; MDA, malondialdehyde; CRP, C-reactive protein; Fib, fibrinogen; ESD, erythrocyte superoxide dismutase; ADMA, asymmetric dimethylarginine; VCAM-1, vascular cell adhesion molecule-1; SDMA, symmetric dimethylarginine; MI, myocardial infarction; IL-6, interleukin-6; STAT-1, signal transducer and activator of transcription 1; OR, odds ratio; SMD, standard mean difference; CI, confidence interval; SD, standard deviation; $\mathrm{P}_{\mathrm{Q}}$, Cochran's Q statistics; $I^{2}$, Higgins $I^{2}$ statistics; SE, standard error; $\mathrm{n}_{\mathrm{st}}$, number of studies.

Received: September 25, 2016; Revised: February 20, 2017; Accepted: February 24, 2017

*Correspondence to: Himanshu Rai, Department of Cardiology, Sanjay Gandhi Post Graduate Institute of Medical Sciences, Raebareli Road, Lucknow-226014, Uttar Pradesh, India. Tel: +91-9919002764, E-mail: himanshurai1981@gmail. com

How to cite this article: Rai H, Sinha N. Genetic Determinants and Biochemical Correlates of Slow Coronary Flow: A Systematic Review and Meta-analysis. Explor Res Hypothesis Med 2017;2(1):12-27. doi: 10.14218/ERHM.2016.00010.
For $27 \mathrm{bp}$ VNTR $\left(\mathrm{n}_{\mathrm{st}}=2\right)$, the OR range was 2.18-2.37, with a $Z$ value range of 3.02-3.10 and $p$-value range of $0.002-0.003$. We also noted possible involvement of some other SNPs which were reported to be associated with SCF in single studies. Our metaanalysis also aimed to assess biochemical correlates of SCF and deduced some noteworthy results. Plas$\mathrm{ma} /$ serum levels of homocysteine $\left[\mathrm{n}_{\mathrm{st}}=10\right.$, standard mean difference (SMD): 1.45 (95\% Cl: 0.95-1.95, $p<0.00001$ ], endothelin-1 [ $\mathrm{n}_{\mathrm{st}}=3, \mathrm{SMD}: 2.33(95 \% \mathrm{Cl}$ : $0.16-4.49), p=0.03]$ and C-reactive protein $\left[\mathrm{n}_{\mathrm{st}}=2\right.$, SMD: 0.39 (95\% Cl: 0.06-0.72), $p=0.02$ ] were found to be positively correlated with SCF, yielding statistically significant results. On the other hand, plasma levels of nitric oxide $\left[\mathrm{n}_{\mathrm{st}}=8\right.$, SMD: -0.93 (95\%Cl: -1.59 to -0.28$), p=0.005]$ and folate $\left[n_{s t}=3\right.$, SMD: -0.62 $(95 \% \mathrm{Cl}=-0.88$ to -0.36$), p<0.00001]$ were found to be significantly, but negatively, correlated with SCF. A few lesser-known biochemical entities reported to be associated with SCF were also identified by single studies. 
Conclusions: The results of this first ever review and meta-analysis on SCF identify its few genetic determinants as well as some biochemical correlates. Implicated biochemical correlates have the potential to be used for early detection of SCF. Published studies evaluating the genetic determinants responsible for this condition, however, are very few and sporadic. Several large and statistically-powered genetic-association studies are required to substantiate our findings.

\section{Introduction}

Slow coronary flow (SCF) was first reported in 1972. It is an angiographically observed phenomenon, characterized by slow antegrade progression of radio-opaque contrast agent in human epicardial arteries, without evidence of any significant obstructive coronary artery disease (CAD). ${ }^{1,2}$ SCF has emerged as an important clinical entity, as it can cause precordial pain during exercise or even at rest. The prevalence of SCF, serious enough to create the clinical suspicion of CAD and thus necessitating a diagnostic coronary angiography, is around $7 \% .^{3}$

SCF is both a rare condition and more likely to be seen in young male smokers who present with recurrent, typical, anginal chest pain. Some cases of sudden cardiac deaths have been attributed to SCF. ${ }^{4}$ Diagnosis of SCF may be made during a standard coronary angiography by using the thrombolysis in myocardial infarction-frame count (TIMI-FC) technique; a method first described by Gibson and colleagues in $1996 .^{5}$ This proposed process is standard, well-explained and widely used. Coronary flow rates are calculated separately for each major coronary artery of each subject, which is followed by the generation of mean TIMI-FCs for each artery of each subject. As different durations are required for normal visualization of different coronary arteries (due to their differences in lengths), the standard-corrected cut-off values usually used are: (a) $36.2 \pm 2.6$ frames for the left anterior descending coronary artery (LAD); (b) $22.2 \pm 4.1$ frames for the left circumflex artery (LCX); (c) 20.4 \pm 3 frames for the right coronary artery (RCA). The subjects with mean TIMI-FCs greater than 2 standard deviations (SDs) from these cut-offs, for any particular vessel, are considered as SCF patients. ${ }^{5}$

Small vessel disease, endothelial dysfunction, microvascular dysfunction and diffuse intimal thickening have been proposed as important etiological factors for $\mathrm{SCF}^{3}$ However, increased coronary microvascular resistance brought about by microvascular endothelial dysfunction coupled with diffused atherosclerosis seems to be the most accepted process underlying the development of SCF. The exact mechanisms leading to the occurrence of coronary microvascular endothelial dysfunction are, however, not completely understood. ${ }^{6,7}$ It is noteworthy though that patients with SCF tend to display impaired flow-mediated dilatation (FMD), which can be studied by a simple, non-invasive method that is otherwise routinely used for assessment of endothelial function. ${ }^{8,9}$

While the etiopathology of SCF is largely unclear, several research groups have attempted to discover the genetic component and biochemical correlates of this condition. ${ }^{10-18}$ Several small, case-control association studies have implicated some of the common single nucleotide polymorphisms (SNPs) residing in a variety of genes as risk factors for SCF. ${ }^{11,12,14,16-18}$ Similarly, several casecontrol studies have also attempted, succeeding in several instances, to discover some of the biochemical correlates of SCF.11,16,17,19${ }^{34}$ Initial review of the literature has shown that these studies are few and sporadic, with relatively modest sample sizes. In any case, consolidation of the generated information will be beneficial.

We, therefore, set out to investigate these datasets as a whole with the objective of determining the genetic component as well as the biochemical correlates of SCF through a systematic review and meta-analysis.

\section{Materials and methods}

We strictly adhered to the specific recommendations of the PRISMA statement and followed the specific directions for genetic meta-analyses published in the HuGE Review Handbook, version 1.0, while conducting our present review and meta-analysis. ${ }^{35}$

\section{Database search}

We systematically searched the databases of the US National Institutes of Health (PubMed), Embase, Medline, Scopus and Web of Knowledge. All relevant, original, full articles, published online up to $31^{\text {st }}$ December 2016 were considered. Search headings and well as open text fields were used to identify specific publications of interest. Databases and the reference lists of the relevant publications were searched using the combination of terms including 'single nucleotide polymorphism' OR 'SNP' OR 'polymorphism' OR 'genetic variation' OR ‘mutation' OR 'biochemical correlates' OR 'biochemical factors' paired with 'SCF' OR 'slow coronary flow' OR 'coronary slow flow' OR 'slow flow in coronary arteries'. The search was restricted to articles relating to humans and published in the English language.

The decision to include studies was made sequentially. Initially, study titles were assessed; if they were deemed relevant, then the abstracts were read, which helped to determine relevance for reading of the full-text in order to test their eligibility for inclusion. To be included in our review, the studies were to have assessed the association between TIMI-FC-defined SCF patients and controls free from SCF. Studies that met all of the following criteria were included in the present review: (1) independent studies using original data, published in English language, in a peer-reviewed journal; (2) unrelated case-control or cohort studies; (3) provision of complete data with genotype frequencies and/or mean levels and the SDs of tested biochemical correlates (or their proxies); (4) SCF diagnosis based on TIMI-FC technique; (5) genotype frequency amongst controls satisfying approximations of Hardy-Weinberg equilibrium (HWE). Departure from HWE amongst controls was checked by goodness-of-fit $x^{2}$ test. Studies were not included in the present meta-analysis if genotype frequencies amongst controls did not conform to HWE approximations $(p<0.05)$. Case reports and the studies not providing adequate information on actual distribution of the tested genetic variant(s) and/or mean and SD level(s) of tested biochemical correlates (or their proxies) amongst both cases and controls were excluded.

Quantitative synthesis was conducted only when there were at least 2 eligible published studies for an SNP or a biochemical factor. Publications that lacked required data were segregated. Formal requests for provision of the relevant data were made via email to the study's corresponding author. If the relevant data was not made available by the corresponding authors (even after three sub- 
Studies investigating genetic component of SCF

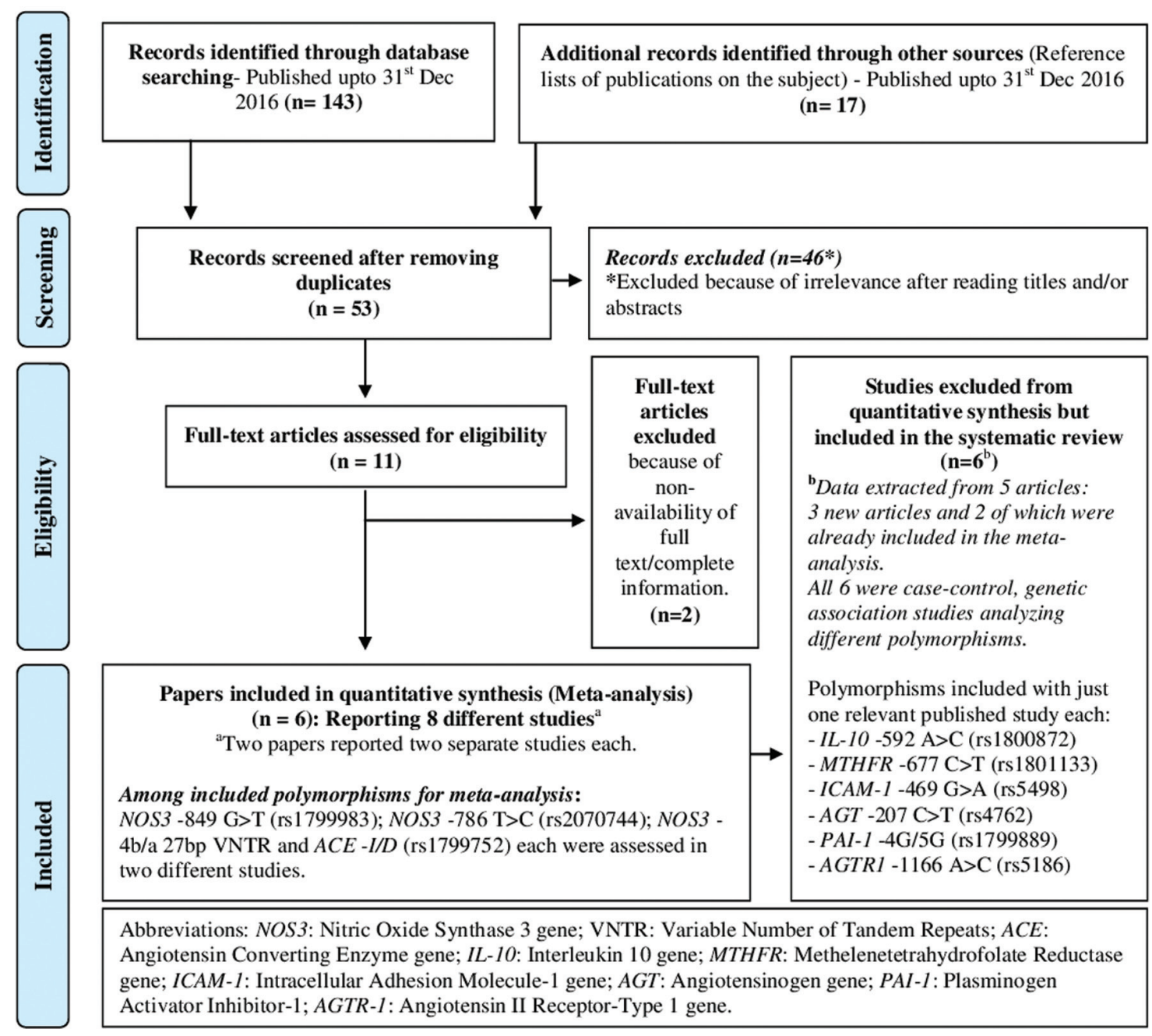

Fig. 1. Study selection procedure: Genetic component of slow coronary flow (SCF).

sequent requests), the article in question was excluded. The raw data was extracted on a paper proforma, and was then transcribed onto a Microsoft Excel worksheet, where further calculations (as needed) were performed.

\section{Statistical techniques}

All calculations for the present meta-analysis were carried out using the Review Manager (RevMan) computer program (version 5.3; The Nordic Cochrane Centre, The Cochrane Collaboration, 2012, Copenhagen). The extracted and tabulated genetic data were further tested by application of dominant, recessive and allelic genetic models, while the data corresponding to biochemical correlates of SCF were extracted and tested using simple case-control comparison.

Owing to inherent low heterogeneity for each selected SNP, an individual study odds ratio (OR) and its $95 \%$ confidence interval (CI), along with a summary OR and its $95 \% \mathrm{CI}$, was calculated for all three genetic models using bivariate-fixed effects for analysis (Mantel-Haenszel method). ${ }^{36}$ Individual ORs, with their corre- sponding 95\%CI were used to reveal the association for the studied SNP with SCF in a particular study. Based on the individual ORs, the pooled/summary OR was estimated using the $Z$ test, where a resulting $p<0.05$ indicated statistical significance, and the corresponding $Z$ value indicated the level of association.

All comparisons for biochemical correlates were simple; standard mean difference (SMD) between cases and controls for each study was calculated with the corresponding 95\%CI. Results yielding statistical significance were identified, where both the calculated SMD and CI of the study in question were lying completely within either side of the plot and not transversing the central line. In case the calculated CI of a study transversed the central line of the plot, the result was considered as inconclusive. The use of random or fixed effects for analysis was based on the inherent heterogeneity within the study group. Study groups for which Cochran's $\mathrm{Q}$ statistics $\left(\mathrm{P}_{\mathrm{Q}}\right)$ yielded a value of $\leq 0.01$ and/or Higgins $I^{2}$ statistics $\left(I^{2}\right)$ yielding a value of $\geq 50 \%$ were identified as heterogeneous, which consequently necessitated the use of a random effects method (i.e. DerSimonian-Laird method) for analysis. ${ }^{37}$ Conversely, groups yielding an $I^{2}$ value of $<50 \%$ along with a $\mathrm{P}_{\mathrm{O}}$ of $>0.01$ were considered homogenous, and a fixed effects method 
was used for analysis. ${ }^{36}$ Based on the individual SMDs and their $95 \% \mathrm{CIs}$, the summary SMD and its $95 \% \mathrm{CI}$ was estimated using $Z$ test, where the resulting $p<0.05$ indicated statistical significance, and the corresponding $Z$ value indicated the level of significance of the derived result.

The influence of publication bias represents a grave concern in meta-analyses of non-randomized observational studies. In the present meta-analysis, publication bias assessment was done for groups of $\geq 3$ studies, employing Begg's funnel plot analysis. ${ }^{38}$ Each point in such a plot represents the OR/SMD for each included study plotted against standard error (SE) of its OR/SMD. Sensitivity analysis was also performed for groups with $\geq 5$ studies. We excluded one study after another and then repeated the analysis after each omission. This was done to observe if the pooled result altered substantially from the positive significant association to lack of association or the other way around. Absence of such alteration in the results is generally indicative of robustness of the meta-analysis in question.

\section{Results}

Records in PubMed, Embase, Medline, Scopus and the Web of Knowledge were thoroughly searched for articles of interest. Figure 1 depicts the study selection procedure of the studies investigating the genetic component of SCF. Amongst the 11 full-text articles assessed for eligibility, 2 were excluded, and 6 reporting 8 different studies supplied data for meta-analysis and 5 articles (including 2 that were already used in our meta-analysis) supplied data from 6 different studies which were used only for the present review. Relevant data extracted from these 14 different studies are displayed in Table $1 .{ }^{10-18}$

A similar rigorous search was also conducted for identifying studies on biochemical correlates of SCF. Figure 2 depicts the detailed study selection procedure. Amongst the 20 full-text articles assessed for eligibility, 2 were excluded, and 17 articles reporting 33 different studies supplied data for meta-analysis and 7 articles (including 5 that were already used in our meta-analysis) supplied data from 13 different studies which were used only for the review. Relevant data extracted from these 46 different studies are displayed in Table 2.11,16,17,19-34

A total of four polymorphisms were included for quantitative synthesis. Three of them resided in the nitric oxide synthase 3 (NOS3) gene, while one was in the angiotensin-converting enzyme $(A C E)$ gene. The four studies had a total sample size of 1,045 (392 cases and 653 controls), which was assessed by quantitative synthesis. The assessed polymorphisms were: rs1799983 (NOS3 849 $\mathrm{G}>\mathrm{T}$; in 2 studies, total sample of 312 (93 cases/219 controls); $; 0,11$ rs2070744 (NOS3 $786 \mathrm{~T}>\mathrm{C}$; in 2 studies, total sample of 174 (89 cases/85 controls); ${ }^{12,18}$ NOS3 4b/a 27 base pair (bp) variable number of tandem repeats (VNTR; in 2 studies, total sample of 402 (123 cases/279 controls); and rs1799752 (ACE I/D; in 2 studies, total sample of 157 ( 87 cases/70 controls). ${ }^{10-12,14,15,18}$

Two of the three evaluated polymorphisms belonging to the NOS3 gene (i.e. rs1799983, NOS3 849 G>T and NOS3 4b/a 27bp VNTR) were found to be associated with SCF. Results for rs 1799983 (NOS3 $849 \mathrm{G}>\mathrm{T}$ ) in two out of the three genetic models (i.e. dominant and allelic models) showed significant association to SCF, indicating that the ' $\mathrm{T}$ ' allele itself imparts a higher risk for developing $\mathrm{SCF}$. Constructed dominant and allelic genetic models showed significant association (pooled OR: 2.71, 95\%CI: 1.41-5.20, $p=0.003$, $Z=3.00$ and pooled OR: $2.11,95 \%$ CI: $1.28-3.49, p=0.004, Z=2.91$ respectively). Results from the recessive genetic model, however, did not reach statistical significance ( $p=0.19$ ). (Fig. 3A-C) Results for NOS3 4b/a 27bp VNTR also displayed a similar trend, where both the dominant and allelic genetic models showed significant association with SCF (pooled OR: 2.37, 95\%CI: 1.35-4.15, $p=0.003$, $Z=3.02$ and pooled OR: $2.18,95 \% \mathrm{CI}: 1.33-3.58, p=0.002, Z=3.10$ respectively), while the results from the recessive genetic model did not reach statistical significance $(p=0.25)$. (Fig. 4A-C) These results indicated that the presence of 'a' allele in a genotype imparts a higher risk to an individual for development of SCF.

Conversely, quantitative synthesis for rs2070744 (NOS3 786 $\mathrm{T}>\mathrm{C}$ ) yielded non-significant results for all three models (i.e. dominant, recessive and allelic models with $p=0.16,0.70$ and 0.34 respectively), suggesting its lack of association with SCF. (Fig. S1A-C) Such results were also seen for rs1799752 (ACE I/D), where none of the 3 constructed genetic models were able to demonstrate significant association $(p=0.27,0.33$ and 0.19 for dominant, recessive and allelic models respectively). (Fig. S2A-C)

Our present review also obtained results for several other SNPs evaluated for association with SCF, which were available in single studies. (Table 1) A study that evaluated rs 1800872 (592 $\mathrm{A}>\mathrm{C})$, a SNP of the interleukin-10 (IL-10) gene, reported significant associations for genotypic distribution for patient versus controls amongst a total sample of 250 (209 cases/41 controls, with $p=0.0280$ for genetic distribution amongst two groups and $p=0.0054$ for the allelic genetic model).${ }^{16}$ Additionally, SNPs like rs1801133 $(677 \mathrm{C}>\mathrm{T})$ from the methylene tetrahydrofolate reductase $($ MTHFR $)$ gene and rs5498 $(469 \mathrm{G}>\mathrm{A})$ from the intercellular adhesion molecule-1 (ICAM-1) gene also showed significant associations with SCF. ${ }^{13,17}$ For rs1801133, the total sample was 75 , including 50 cases and 25 controls, with $p=0.029$ for the dominant genetic model and $p=0.042$ for the allelic genetic model. For rs 5498 , the total sample was 115 , including 48 cases and 67 controls, with $p=0.013$ for the allelic genetic model.

However, some other SNPs evaluated from the single studies (e.g. rs4762 from the angiotensinogen (AGT) gene, rs1799889 from the plasminogen activator inhibitor-1(PAI-1) gene and rs5186 from the angiotensin II receptor type 1(AGTRl) gene) were not found to be associated with SCF ( $p>0.05$ for all). ${ }^{13,15,18}$

Seventeen articles with 33 studies were included in the metaanalysis for the discovery of biochemical correlates for SCF. Serum nitric oxide (NO) was evaluated in 8 studies with a total sample of 625 , including 253 cases and 372 controls. ${ }^{11,19-21,27,30,31,33}$ Homocysteine (Hcy) was evaluated in 10 studies with a total sample of 819 , including 448 cases and 371 controls. ${ }^{17,22-26,28-30,32}$ Folate (in a total sample of 249 , including 137 cases and 112 controls), endothelin-1 (ET-1) (in a total sample of 145, including 86 cases and 59 controls), and malondialdehyde (MDA) (in a total sample of 215 , including 116 cases and 99 controls) were each evaluated in 3 studies, while C-reactive protein (CRP) (total sample of 148, including 84 cases and 64 controls), fibrinogen (Fib) (total sample of 160, including 94 cases and 66 controls), erythrocyte superoxide dismutase (ESD) (total sample of 152 , including 76 cases and 76 controls) and asymmetric dimethylarginine (ADMA) (total sample of 143 , including 90 cases and 53 controls) were evaluated in 2 studies each. ${ }^{17,19,20,24-29,33}$

In our quantitative synthesis (conducted using appropriate effects for analysis), we found several biochemical entities yielding significant correlations with SCF. SCF cases were found to have significantly lower plasma NO concentrations as compared to controls (SMD: -0.93 , 95\%CI: -1.59 to $-0.28, p=0.005, Z=2.79$ ). (Fig. $5 \mathrm{~A})$ In contrast, SCF cases appeared to be associated with higher serum concentrations of Hcy as compared to controls (SMD: 1.45, 95\%CI: 0.95-1.95, $p=<0.00001, Z=5.63$ ). (Fig. 5B) SCF cases also appeared to have significantly lower plasma folate concentrations 
Table 1. Genetic association studies on slow coronary flow

\begin{tabular}{|c|c|c|c|c|c|c|c|}
\hline $\begin{array}{l}\text { Evaluated } \\
\text { Gene }\end{array}$ & $\begin{array}{l}\text { SNP } \\
\text { studied }\end{array}$ & $\begin{array}{l}\text { Study, } \\
\text { Year }\end{array}$ & $\begin{array}{l}\text { Country, } \\
\text { Ancestry }\end{array}$ & $\begin{array}{l}\text { MAF } \\
\text { (Cases/ } \\
\text { Controls) }\end{array}$ & $\begin{array}{l}\text { Total sample } \\
\text { size (Cases/ } \\
\text { Controls) }\end{array}$ & $\begin{array}{l}\text { Genotypic dis- } \\
\text { tribution (Cases } \\
\text { and Controls }\end{array}$ & Result \\
\hline \multirow[t]{6}{*}{ NOS3 } & $\begin{array}{l}\text { rs1799983 } \\
(849 \mathrm{G}>\mathrm{T})\end{array}$ & $\begin{array}{l}\text { Caglayan } \\
\text { et al., } \\
2009^{10}\end{array}$ & $\begin{array}{l}\text { Turkey, } \\
\text { Middle } \\
\text { Eastern } \\
\text { Ancestry }\end{array}$ & $0.46 / 0.37$ & $85(66 / 19)$ & $\begin{array}{l}\mathrm{GG}=17 ; \mathrm{GT}=37 ; \\
\mathrm{TT}=12 \text { in cases } \\
\mathrm{AND} \\
\mathrm{GG}=8 ; \mathrm{GT}=8 ; \\
\mathrm{TT}=3 \text { in controls }\end{array}$ & $\begin{array}{l}\text { No association of rs1799983 with } \\
\text { SCF was observed. }\end{array}$ \\
\hline & & $\begin{array}{l}\text { Gupta et } \\
\text { al., } 2014^{11}\end{array}$ & $\begin{array}{l}\text { India; } \\
\text { Asian } \\
\text { Indian } \\
\text { Ancestry }\end{array}$ & $0.30 / 0.12$ & $227(27 / 200)$ & $\begin{array}{l}\mathrm{GG}=14 ; \mathrm{GT}=10 ; \\
\mathrm{TT}=3 \text { in cases } \\
\mathrm{AND} \\
\mathrm{GG}=155 ; \mathrm{GT}=41 ; \\
\mathrm{TT}=4 \text { in controls }\end{array}$ & $\begin{array}{l}\text { Strong association was seen } \\
\text { for TT genotype and 'T' allele } \\
\text { resulting due to rs } 1799983 \text { with } \\
\text { SCF. Dominant genetic model } \\
\text { comparisons (GT+TT vs. GG) also } \\
\text { indicated significant } \\
\text { association with SCF. }\end{array}$ \\
\hline & $\begin{array}{l}\text { rs2070744 } \\
(786 \mathrm{~T}>\mathrm{C})\end{array}$ & $\begin{array}{l}\text { Nurkalem } \\
\text { et al., } \\
2008^{12}\end{array}$ & $\begin{array}{l}\text { Turkey, } \\
\text { Middle } \\
\text { Eastern } \\
\text { Ancestry }\end{array}$ & $0.34 / 0.23$ & $93(56 / 37)$ & $\begin{array}{l}\mathrm{TT}=22 ; \mathrm{TC}=30 ; \\
\mathrm{CC}=4 \text { in cases } \\
\mathrm{AND} \\
\mathrm{TT}=23 ; \mathrm{TC}=11 ; \\
\mathrm{CC}=3 \text { in controls }\end{array}$ & $\begin{array}{l}\text { Significant association was } \\
\text { seen for ' } C \text { ' (major) allele with } \\
\text { SCF. Presence of ' } C \text { ' allele in a } \\
\text { genotype was identified as a risk } \\
\text { factor for SCF. }\end{array}$ \\
\hline & & $\begin{array}{l}\text { Gazi et al., } \\
2014^{18}\end{array}$ & $\begin{array}{l}\text { Turkey, } \\
\text { Middle } \\
\text { Eastern } \\
\text { Ancestry }\end{array}$ & $0.26 / 0.28$ & $81(33 / 48)$ & $\begin{array}{l}\mathrm{TT}=18 ; \mathrm{TC}=13 ; \\
\mathrm{CC}=2 \text { in cases } \\
\mathrm{AND} \\
\mathrm{TT}=25 ; \mathrm{TC}=19 ; \\
\mathrm{CC}=4 \text { in controls }\end{array}$ & $\begin{array}{l}\text { No association of rs } 2070744 \text { with } \\
\text { SCF was observed. }\end{array}$ \\
\hline & $\begin{array}{l}4 \mathrm{~b} / \mathrm{a} 27 \mathrm{bp} \\
\text { VNTR }\end{array}$ & $\begin{array}{l}\text { Ekmekci } \\
\text { et al., } \\
2013^{14}\end{array}$ & $\begin{array}{l}\text { Turkey, } \\
\text { Middle } \\
\text { Eastern } \\
\text { Ancestry }\end{array}$ & $0.19 / 0.08$ & $175(96 / 79)$ & $\begin{array}{l}b / b=64 ; b / a=28 ; \\
a / a=4 \text { in cases } \\
\text { AND } \\
b / b=67 ; b / a=12 ; \\
a / a=0 \text { in controls }\end{array}$ & $\begin{array}{l}\text { Allele ' } a \text { ' and its carriers were } \\
\text { both found to be significantly } \\
\text { associated with SCF. }\end{array}$ \\
\hline & & $\begin{array}{l}\text { Gupta et } \\
\text { al., } 2014^{11}\end{array}$ & $\begin{array}{l}\text { India; } \\
\text { Asian } \\
\text { Indian } \\
\text { Ancestry }\end{array}$ & $0.19 / 0.13$ & $227(27 / 200)$ & $\begin{array}{l}b / b=18 ; b / a=8 ; \\
a / a=1 \text { in cases } \\
\text { AND } \\
b / b=157 ; b / a=34 ; \\
a / a=9 \text { in controls }\end{array}$ & $\begin{array}{l}\text { Over-dominant genetic model } \\
\text { (b/b }+a / a \text { vs. b/a) suggested } \\
\text { the association of heterozygous } \\
\text { genotype 'b/a' with SCF. On the } \\
\text { other hand both alleles ' } a \text { ' and ' } b \text { ' } \\
\text { and genotypes } a / a \text { and } b / b \text { did } \\
\text { not seem to be independently } \\
\text { associated with SCF. }\end{array}$ \\
\hline \multirow[t]{2}{*}{$A C E$} & $\begin{array}{l}\text { rs1799752 } \\
\text { (I/D) }\end{array}$ & $\begin{array}{l}\text { Yalcin et } \\
\text { al., } 2009^{15}\end{array}$ & $\begin{array}{l}\text { Turkey, } \\
\text { Middle } \\
\text { Eastern } \\
\text { Ancestry }\end{array}$ & $0.31 / 0.52$ & $76(54 / 22)$ & $\begin{array}{l}\mathrm{DD}=27 ; \mathrm{DI}=21 ; \\
\mathrm{II}=6 \text { in cases } \\
\text { AND } \\
\mathrm{DD}=6 ; \mathrm{DI}=9 ; \mathrm{II}=7 \\
\text { in controls }\end{array}$ & $\begin{array}{l}\text { Borderline association for } \\
\text { rs1799752 with SCF was seen. } \\
\text { Carriers of "D" (major) allele were } \\
\text { seen to have higher odds } \\
\text { for developing SCF. }\end{array}$ \\
\hline & & $\begin{array}{l}\text { Gazi et al., } \\
2014^{18}\end{array}$ & $\begin{array}{l}\text { Turkey, } \\
\text { Middle } \\
\text { Eastern } \\
\text { Ancestry }\end{array}$ & $0.44 / 0.41$ & $81(33 / 48)$ & $\begin{array}{l}\mathrm{DD}=11 ; \mathrm{DI}=15 ; \\
\mathrm{II}=7 \text { in cases } \\
\text { AND } \\
\mathrm{DD}=17 ; \mathrm{DI}=23 ; \\
\|=8 \text { in controls }\end{array}$ & $\begin{array}{l}\text { No association of rs1799752 with } \\
\text { SCF was observed. }\end{array}$ \\
\hline$I L-10$ & $\begin{array}{l}\text { rs1800872 } \\
(592 \mathrm{~A}>\mathrm{C})\end{array}$ & $\begin{array}{l}\text { Shi et al., } \\
2015^{16}\end{array}$ & $\begin{array}{l}\text { China, } \\
\text { Asian } \\
\text { Ancestry }\end{array}$ & $0.19 / 0.33$ & $250(209 / 41)$ & $\begin{array}{l}A A=209 ; A C=60 ; \\
C C=10 \text { in cases } \\
A N D \\
A A=19 ; A C=17 ; \\
C C=5 \text { in controls }\end{array}$ & $\begin{array}{l}\text { A strong association of rs } 1800872 \\
\text { with SCF was observed. Allele 'A' } \\
\text { (major allele) itself and its carriers } \\
\text { were seen to have higher odds } \\
\text { for developing SCF. Conversely; } \\
\text { allele 'C' (minor allele) and its } \\
\text { carriers were observed to carry } \\
\text { significantly lower odds for } \\
\text { developing SCF. }\end{array}$ \\
\hline MTHFR & $\begin{array}{l}\text { rs1801133 } \\
(677 \mathrm{C}>\mathrm{T})\end{array}$ & $\begin{array}{l}\text { Tang et } \\
\text { al., 2014 }\end{array}$ & $\begin{array}{l}\text { China, } \\
\text { Asian } \\
\text { Ancestry }\end{array}$ & $0.43 / 0.26$ & $75(50 / 25)$ & $\begin{array}{l}C C=15 ; C T=27 \\
T T=8 \text { in cases } \\
\text { AND } \\
C C=14 ; C T=9 ; \\
T T=2 \text { in controls }\end{array}$ & $\begin{array}{l}\text { A strong association of rs } 1801133 \\
\text { with SCF was observed. Carriers } \\
\text { of "T" (minor) allele were seen to } \\
\text { have higher odds for developing } \\
\text { SCF. }\end{array}$ \\
\hline
\end{tabular}


Table 1. Genetic association studies on slow coronary flow - (continued)

\begin{tabular}{|c|c|c|c|c|c|c|c|}
\hline $\begin{array}{l}\text { Evaluated } \\
\text { Gene }\end{array}$ & $\begin{array}{l}\text { SNP } \\
\text { studied }\end{array}$ & $\begin{array}{l}\text { Study, } \\
\text { Year }\end{array}$ & $\begin{array}{l}\text { Country, } \\
\text { Ancestry }\end{array}$ & $\begin{array}{l}\text { MAF } \\
\text { (Cases/ } \\
\text { Controls) }\end{array}$ & $\begin{array}{l}\text { Total sample } \\
\text { size (Cases/ } \\
\text { Controls) }\end{array}$ & $\begin{array}{l}\text { Genotypic dis- } \\
\text { tribution (Cases } \\
\text { and Controls }\end{array}$ & Result \\
\hline ICAM-1 & $\begin{array}{l}r s 5498 \\
(469 \mathrm{G}>A)\end{array}$ & $\begin{array}{l}\text { Gazi et al., } \\
2014(a)^{13}\end{array}$ & $\begin{array}{l}\text { Turkey, } \\
\text { Middle } \\
\text { Eastern } \\
\text { Ancestry }\end{array}$ & $0.47 / 0.63$ & $115(48 / 67)$ & $\begin{array}{l}G G=12 ; G A=27 ; \\
A A=9 \text { in cases } \\
A N D \\
G G=8 ; G A=33 ; \\
A A=26 \text { in controls }\end{array}$ & $\begin{array}{l}\text { A strong association of rs5498 } \\
\text { with SCF was observed. Allele } \\
\text { 'G' (major allele) and its carriers } \\
\text { were seen to have significantly } \\
\text { higher odds for developing SCF. } \\
\text { Conversely, Allele 'A' (minor } \\
\text { allele) and its carriers were found } \\
\text { to be protected against SCF and } \\
\text { were seen to have significantly } \\
\text { lower odds for developing SCF. }\end{array}$ \\
\hline$A G T$ & $\begin{array}{l}\text { rs4762 } \\
(207 \mathrm{C}>\mathrm{T})\end{array}$ & $\begin{array}{l}\text { Gazi et al., } \\
2014(a)^{13}\end{array}$ & $\begin{array}{l}\text { Turkey, } \\
\text { Middle } \\
\text { Eastern } \\
\text { Ancestry }\end{array}$ & $0.14 / 0.10$ & $115(48 / 67)$ & $\begin{array}{l}\mathrm{CC}=36 ; \mathrm{CT}=11 ; \\
\mathrm{TT}=1 \text { in cases } \\
\text { AND } \\
\mathrm{CC}=54 ; \mathrm{CT}=12 ; \\
\mathrm{TT}=1 \text { in controls }\end{array}$ & $\begin{array}{l}\text { No association of rs } 4762 \text { with SCF } \\
\text { was observed. }\end{array}$ \\
\hline PAI-I & $\begin{array}{l}\text { rs1799889 } \\
(4 G / 5 G)\end{array}$ & $\begin{array}{l}\text { Gazi et al., } \\
2014^{18}\end{array}$ & $\begin{array}{l}\text { Turkey, } \\
\text { Middle } \\
\text { Eastern } \\
\text { Ancestry }\end{array}$ & $0.58 / 0.45$ & $81(33 / 48)$ & $\begin{array}{l}5 G / 5 G=10 ; \\
5 G / 4 G=18 ; \\
4 G / 4 G=5 \text { in cases } \\
\text { AND } \\
5 G / 5 G=11 ; \\
5 G / 4 G=21 ; \\
4 G / 4 G=16 \text { in } \\
\text { controls }\end{array}$ & $\begin{array}{l}\text { No association of rs1799889 with } \\
\text { SCF was observed. }\end{array}$ \\
\hline AGTR1 & $\begin{array}{l}\text { rs5186 } \\
(1166 \text { A }>C)\end{array}$ & $\begin{array}{l}\text { Yalcin et } \\
\text { al., } 2009^{15}\end{array}$ & $\begin{array}{l}\text { Turkey, } \\
\text { Middle } \\
\text { Eastern } \\
\text { Ancestry }\end{array}$ & $0.29 / 0.34$ & $76(54 / 22)$ & $\begin{array}{l}A A=31 ; A C=15 ; \\
C C=8 \text { cases } \\
A N D \\
A A=10 ; A C=9 ; \\
C C=3 \text { in controls }\end{array}$ & $\begin{array}{l}\text { No association of rs5186 with SCF } \\
\text { was observed. }\end{array}$ \\
\hline
\end{tabular}

SNP: Single nucleotide polymorphisms; MAF: Minor allele frequency; SCF: Slow coronary flow; NOS3: Nitric Oxide Synthase 3; ACE: Angiotensin-converting enzyme; IL-10: Interleukin-10; MTHFR: Methylene tetrahydrofolate reductase; ICAM-1: Intercellular Adhesion Molecule-1; AGT: Angiotensinogen; PAI-1: Plasminogen activator inhibitor-1; AGTR1: Angiotensin II Receptor, Type 1; TIMI-FC: Thrombolysis in myocardial infarction-frame count.

SCF assessment tool used in all included studies was TIMI-FC.

(SMD: $-0.62,95 \% \mathrm{CI}:-0.88$ to $-0.36, p=<0.00001, Z=4.69)$. (Fig. $5 \mathrm{C})$ On the other hand, ET-1 and CRP levels were found to be significantly higher among the SCF cases as compared to the controls (SMD: 2.33 , 95\%CI: 0.16 to $4.49, p=0.03, Z=2.11$ for ET-1; SMD: $0.39,95 \%$ CI: 0.06 to $0.72, p=0.02, Z=2.29$ for CRP). (Fig. $5 \mathrm{D}-\mathrm{E}$ ).

We found a lack of association for MDA, Fib, ESD and ADMA levels with SCF in the present meta-analysis ( $p>0.05$ for all). (Fig. S3A-D).

Some other circulating biochemical entities also have been investigated for SCF in the past via single studies. (Table 2) Turhan and colleagues reported statistically higher levels of ICAM-1, vascular cell adhesion molecule-1 (VCAM-1) and E-selectin in SCF cases as compared to controls. ${ }^{34}$ Uric acid levels were also found to be statistically higher, while IL-10, glutathione, and erythrocyte catalase, levels were found to be statistically lower among the SCF cases as compared to the controls. ${ }^{16,17,26,27}$ As for other factors, like myeloperoxidase, ADMA, symmetric dimethylarginine (SDMA), arginine and vitamin $\mathrm{B} 12$, the association remained inconclusive. ${ }^{25,28}$

Begg's funnel plots were used to evaluate the existence of publication bias in groups with $\geq 3$ studies. ${ }^{38}$ Study groups for only two biochemical correlates (i.e. NO and Hcy) qualified these preset criteria. Figure S4A-B display the plots for study groups evaluating $\mathrm{NO}$ and Hcy respectively. Most of the points in both the plots were found to be generally contained within the inverted cone, indicating no significant bias. (Fig. S4A-B) Sensitivity analysis was performed to verify the results of the aforementioned correlates and also attested to the robustness of the pooled results (data not shown).

\section{Discussion}

The present manuscript is the first of its kind, entailing a metaanalysis and a systematic review of published studies evaluating the genetic component as well as the biochemical correlates of SCF. This present review includes every relevant study published on the subject to date. Genotypic frequencies of controls included in all selected studies, for all included SNPs, satisfied the HWE approximations $(p>0.05)$. The present systematic review and metaanalysis clearly indicates that SCF might have a prominent genetic component and several important biochemical correlates.

\section{Genetic component of SCF}

The present meta-analysis showed an association of two NOS3 gene polymorphisms (i.e. rs1799983 NOS3 $849 \mathrm{G}>\mathrm{T}$, and NOS3 $4 \mathrm{~b} / \mathrm{a} 27 \mathrm{bp}$ VNTR) with SCF via two genetic models each (i.e. dominant and allelic). Recently published meta-analyses suggest undeniable involvements of both these SNPs with CAD as well as myocardial infarction (MI). ${ }^{39,40}$

The NOS3 $849 \mathrm{G}>\mathrm{T}$ gene polymorphism was first described in 


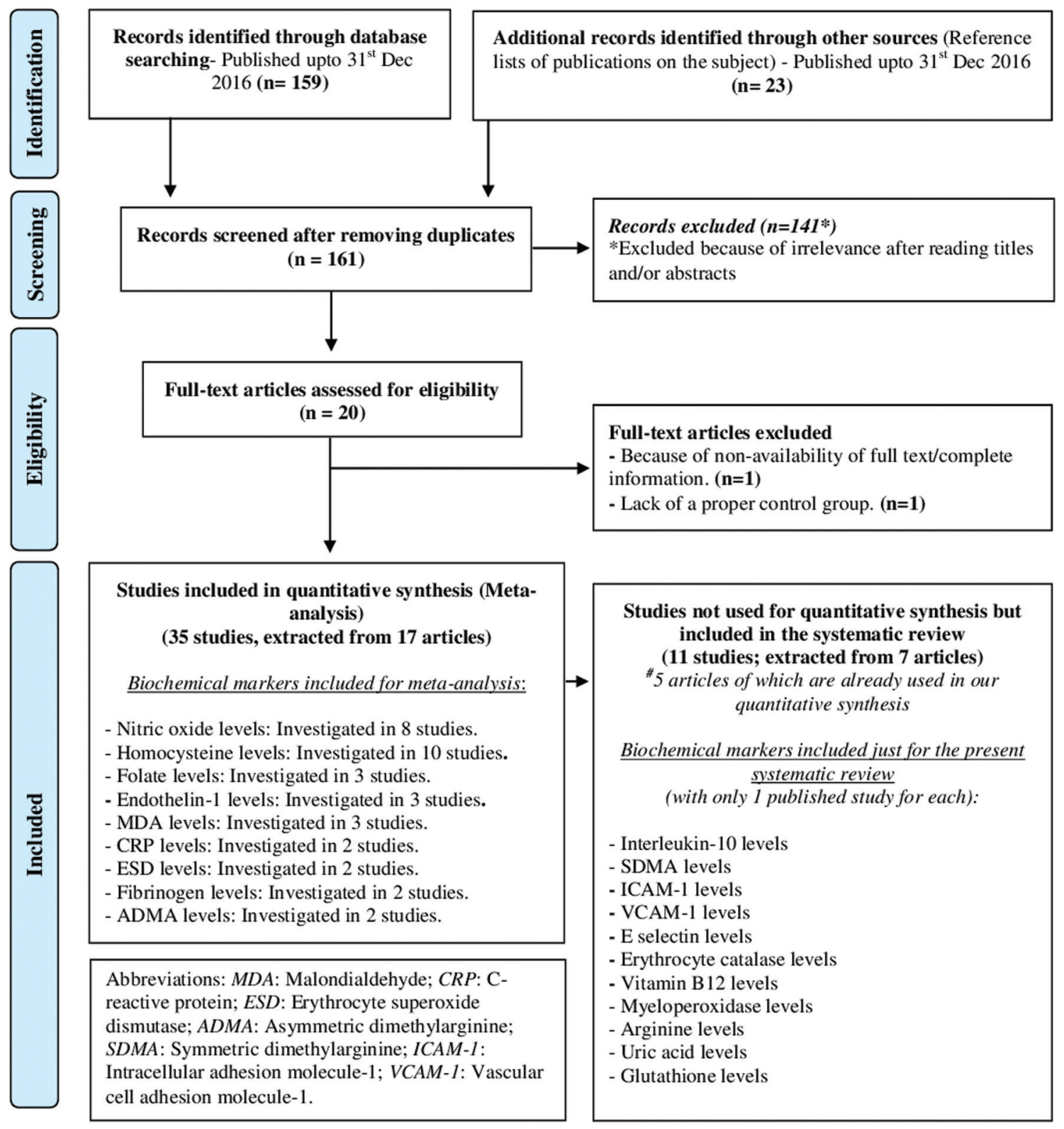

Fig. 2. Study selection procedure: Biochemical correlates of slow coronary flow (SCF).

$1995 .{ }^{41}$ It results from a naturally occurring point replacement of guanine $(\mathrm{G})$ to thymine $(\mathrm{T})$ at nucleotide 1917 in exon 7 of the NOS3 gene. The consequence of this is a further replacement of glutamic acid by aspartic acid at codon 298, known as Glu298Asp (also commonly referred to as $894 \mathrm{G}>\mathrm{T}$ ). There has been controversy on the functional status of this SNP. Since this SNP was first described, it has been associated with lower concentrations of intracellular NO by some, while others have found non-association with $\mathrm{NO}$ levels. ${ }^{42,43}$

Regardless of their genetic composition, SCF cases have been shown to have lower levels of plasma NO. ${ }^{30}$ If this SNP is truly associated with lower intracellular NO production, then further decreased concentrations among SCF cases may accelerate the rate of endothelial dysfunction. Published reports indicate that endothelial dysfunction might be the most prominent etiological factor behind SCF, which probably is the reason why this association is seen in the present meta-analysis. ${ }^{19}$ Befittingly, in addition to CAD and MI, this SNP has also been associated with coronary artery spasm and hypertension. ${ }^{44,45}$ Distinct geo-ethnic differences are also seen between the two included studies for the NOS3 894 $\mathrm{G}>\mathrm{T}$ variant. ${ }^{10,11}$ Larger studies of diverse populations are warranted to validate/negate the observed association.

Amongst the several VNTRs that have functional significance within the NOS3 gene, the $27 \mathrm{bp}$ polymorphic repeat in intron 4 , close to the $5^{\prime}$ end of the gene, is certainly one of the most explored in relation to cardiovascular ailments. The resulting, rare 4-repeat 
Table 2. Studies on biochemical markers investigated for their association with slow coronary flow

\begin{tabular}{|c|c|c|c|c|}
\hline Study, Year & Evaluated marker/s & $\begin{array}{l}\text { Country, } \\
\text { Ancestry }\end{array}$ & $\begin{array}{l}\text { Total sample } \\
\text { size (Cases/ } \\
\text { Controls) }\end{array}$ & Result \\
\hline $\begin{array}{l}\text { Camsarl et } \\
\text { al., } 2003^{19}\end{array}$ & $\begin{array}{l}\text { Nitric Oxide; } \\
\text { Endothelin-1 }\end{array}$ & $\begin{array}{l}\text { Turkey, Middle } \\
\text { Eastern Ancestry }\end{array}$ & $45(25 / 20)$ & $\begin{array}{l}\text { SCF group had statistically lower NO levels at baseline as compared to SCF } \\
\text { free control group }(27 \pm 5.1 \text { vs. } 31.2 \pm 4.9 \mu \mathrm{mol} / \mathrm{L} \text { respectively, } \mathrm{P}=0.0001) \text {. } \\
\text { NO levels increased in both the groups after strenuous exercise, similar } \\
\text { significant differences between the groups still existed after exercise } \\
(29.4 \pm 5.9 \text { vs. } 33.3 \pm 5.6 \mu \mathrm{mol} / \mathrm{L} \text { respectively, } \mathrm{P}=0.0001) \text {. } \\
\text { On the other hand, higher endothelin- } 1 \text { levels at baseline were seen in } \\
\text { the SCF group as compared to } \mathrm{SCF} \text { free control group ( } 11.1 \pm 5.9 \mathrm{vs} 7.0 \pm 4.5 \\
\mathrm{pg} / \mathrm{ml} \text { respectively, } \mathrm{P}<0.0001) \text {. Endothelin- } 1 \text { levels increased in both the } \\
\text { groups after strenuous exercise, similar significant differences still existed } \\
\text { after exercise }(20.1 \pm 10.4 \text { vs. } 6.2 \pm 4.3 \mathrm{pg} / \mathrm{ml} \text { respectively, } \mathrm{P}<0.0001) \text {. }\end{array}$ \\
\hline $\begin{array}{l}\text { Pekdemir } \\
\text { et al., } \\
2004^{20}\end{array}$ & $\begin{array}{l}\text { Nitric Oxide; } \\
\text { Endothelin-1 }\end{array}$ & $\begin{array}{l}\text { Turkey, Middle } \\
\text { Eastern Ancestry }\end{array}$ & $44(25 / 19)$ & $\begin{array}{l}\text { Exercise negative SCF group }(n=25) \text { had lower NO levels as compared } \\
\text { to SCF free control group. This difference, although was not statistically } \\
\text { significant }(32.8 \pm 22.7 \text { vs. } 42.5 \pm 15.9 \mu \text { mol/L respectively, } p=N S) \text {. However, } \\
\text { exercise positive SCF group }(n=8) \text { had statistically significantly lower NO } \\
\text { levels as compared to SCF free control group ( } 23.4 \pm 13.5 \text { vs. } 42.5 \pm 15.9 \\
\mu m o l / L \text { respectively, } P<0.05) \text {. } \\
\text { On the other hand, exercise negative SCF group ( } n=25 \text { ) had statistically } \\
\text { higher endothelin-1 levels as compared to SCF free control group } \\
(15.9 \pm 10.6 \text { vs. } 6.0 \pm 5.7 \mathrm{pg} / \mathrm{mL} \text { respectively, } P<0.0001) \text {. Exercise positive SCF } \\
\text { group ( } n=8) \text { also had statistically higher endothelin- } 1 \text { levels as compared } \\
\text { to SCF free controls }(28.7 \pm 17.4 \text { vs. } 6.0 \pm 5.7 \mathrm{pg} / \mathrm{mL} \text { respectively, } P<0.0001) \text {. }\end{array}$ \\
\hline $\begin{array}{l}\text { Sezgin et } \\
\text { al., } 2005^{21}\end{array}$ & Nitric Oxide & $\begin{array}{l}\text { Turkey, Middle } \\
\text { Eastern Ancestry }\end{array}$ & $70(36 / 34)$ & $\begin{array}{l}\text { SCF group had statistically lower NO levels as compared to SCF free control } \\
\text { group }(18.4 \pm 4.4 \text { vs. } 25.2 \pm 6.3 \mu \mathrm{mol} / \mathrm{L} \text { respectively, } \mathrm{P}=0.001) \text {. }\end{array}$ \\
\hline $\begin{array}{l}\text { Barutcu et } \\
\text { al., } 2005^{22}\end{array}$ & Homocysteine & $\begin{array}{l}\text { Turkey, Middle } \\
\text { Eastern Ancestry }\end{array}$ & $69(39 / 30)$ & $\begin{array}{l}\text { SCF group had statistically higher Hcy levels as compared to SCF free } \\
\text { control group }(14.1 \pm 2.2 \text { vs. } 5.5 \pm 1.3 \mu \mathrm{mol} / \mathrm{L} \text { respectively, } \mathrm{P}<0.001) \text {. }\end{array}$ \\
\hline $\begin{array}{l}\text { Riza Erbay } \\
\text { et al., }\end{array}$ & Homocysteine & $\begin{array}{l}\text { Turkey, Middle } \\
\text { Eastern Ancestry }\end{array}$ & $103(53 / 50)$ & $\begin{array}{l}\text { SCF group had statistically higher Hcy levels as compared to SCF free } \\
\text { control group ( } 15.5 \pm 5.7 \text { vs. } 8.6 \pm 4.2 \mu \mathrm{mol} / \mathrm{L} \text { respectively, } \mathrm{P}<0.001) \text {. }\end{array}$ \\
\hline
\end{tabular}

$2005^{23}$

$\begin{array}{lll}\text { Tanriverdi } & \text { Homocysteine; } & \text { Turkey, Middle } 88(44 / 44) \\ \text { et al., } & \text { Folate } & \text { Eastern Ancestry }\end{array}$

SCF group had statistically higher Hcy levels as compared to SCF free control group (12.4 \pm 4.9 vs. $8.5 \pm 2.8 \mu \mathrm{mol} / \mathrm{L}$ respectively, $\mathrm{P}=0.0001)$. On the other hand, SCF group had statistically lower folate levels as compared to SCF free controls $(13.8 \pm 4.4$ vs. $16.5 \pm 5.6 \mathrm{ng} / \mathrm{mL}$ respectively, $\mathrm{P}=0.014)$.

Turhan et ICAM; VCAM; $\quad$ Turkey, Middle $37(17 / 20)$

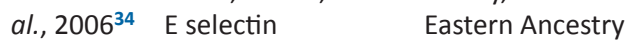

SCF group had statistically higher ICAM, VCAM and E selectin levels as compared to SCF free control group (ICAM-1: $545 \pm 198$ vs. $242 \pm 113 \mathrm{ng} / \mathrm{ml}$ respectively, $p<0.001$; VCAM-1: $2040 \pm 634$ vs. $918 \pm 336 \mathrm{ng} / \mathrm{ml}$ respectively, $\mathrm{p}<0.001$; E-selectin: $67 \pm 9$ vs. $52 \pm 8 \mathrm{ng} / \mathrm{ml}$ respectively, $\mathrm{p}<0.001$ ).

Evrengul et Homocysteine; Turkey, Middle 86 (43/43) al., $2007^{25}$ Folate; Vitamin B12 Eastern Ancestry SCF group had statistically higher Hcy levels as compared to SCF free control group ( $13.4 \pm 5.6$ vs. $7.9 \pm 2.5 \mu \mathrm{mol} / \mathrm{L}$ respectively, $\mathrm{P}=0.0001)$. On the other hand, SCF group had statistically lower folate levels as compared to SCF free control group $(13.2 \pm 4.3$ vs. $17.1 \pm 5.2 \mathrm{ng} / \mathrm{mL}$ respectively, $\mathrm{P}=0.0001$ ).

Vitamin B12 levels were found to be comparable between the two groups ( $287 \pm 96.5$ vs. $290 \pm 72.8 \mathrm{pg} / \mathrm{mL}$ respectively, $\mathrm{P}=\mathrm{NS}$ ).

Tanriverdi Homocysteine; Turkey, Middle 88 (44/44) et al., MDA; ESD; Eastern Ancestry SCF group had statistically higher Hcy, MDA and ESD levels as compared to SCF free control group (Hcy: $12.2 \pm 4.9$ vs. $8.5 \pm 2.9 \mu \mathrm{mol} / \mathrm{L}$ respectively, $\mathrm{P}=0.0001 ; \mathrm{MDA}: 1.65 \pm 1.4$ vs. $1.15 \pm 0.5 \mathrm{nmol} / \mathrm{mL}$ respectively, $\mathrm{P}=0.036$; ESD: 4,249.6 \pm 987.1 vs. 2,560.3 $\pm 765.3 \mathrm{U} / \mathrm{gHb}$ respectively, $\mathrm{P}=0.002$ ). On the other hand, SCF cases had statistically lower glutathione levels as compared to SCF free control group $(7.27 \pm 0.5 \mathrm{vs} .8 .74 \pm 1.3 \mu \mathrm{mol} / \mathrm{gHb}$ respectively, $\mathrm{P}=0.029$ ).

$\begin{array}{lll}\begin{array}{l}\text { Akcay et } \\ \text { al., 201027 }\end{array} & \begin{array}{l}\text { Nitric Oxide; MDA; } \\ \text { ESD; Erythrocyte } \\ \text { catalase }\end{array} & \text { Turkey, Middle 64 (32/32) }\end{array}$
SCF group had statistically lower NO, ESD and Erythrocyte catalase levels at baseline as compared to SCF free control group (NO: $4.1 \pm 1.6$ vs. $6.1 \pm 2.9$ $\mu \mathrm{mol} / \mathrm{L}$ respectively, $\mathrm{P}<0.001$; ESD: $1133.0 \pm 415.3$ vs. $1647.5 \pm 530.4 \mathrm{U} / \mathrm{gHb}$ respectively, $\mathrm{P}<0.0001$; Erythrocyte catalase: $5.3 \pm 1.9$ vs. $7.3 \pm 2.6 \mathrm{U} / \mathrm{gHb}$ respectively, $\mathrm{P}<0.001$ ).

On the other hand, SCF group had statistically higher MDA levels at baseline as compared to SCF free control group ( $3.3 \pm 1.6$ vs. $2.0 \pm 0.6$ $\mathrm{nmol} / \mathrm{mL}$ respectively, $\mathrm{P}<0.0001$ ). 
Table 2. Studies on biochemical markers investigated for their association with slow coronary flow - (continued)

\begin{tabular}{|c|c|c|c|c|}
\hline Study, Year & Evaluated marker/s & $\begin{array}{l}\text { Country, } \\
\text { Ancestry }\end{array}$ & $\begin{array}{l}\text { Total sample } \\
\text { size (Cases/ } \\
\text { Controls) }\end{array}$ & Result \\
\hline $\begin{array}{l}\text { Kopetz et } \\
\text { al., } 2012^{28}\end{array}$ & $\begin{array}{l}\text { Homocysteine; } \\
\text { MDA; CRP; } \\
\text { Myeloperoxidase; } \\
\text { ADMA; SDMA; } \\
\text { Arginine }\end{array}$ & $\begin{array}{l}\text { Australia, } \\
\text { European } \\
\text { Ancestry }\end{array}$ & $63(40 / 23)$ & $\begin{array}{l}\text { SCF group showed trends of higher Hcy and CRP levels as compared to } \\
\text { SCF free control group. The comparisons however did not reach statistical } \\
\text { significance [Hcy: } 9.2 \pm 0.39 \text { (SEM) vs. } 8.3 \pm 0.34 \text { (SEM) } \mu \mathrm{M} \text { respectively, } \\
\mathrm{P}=\mathrm{NS} \text {; CRP: } 3.23 \pm 0.59 \text { (SEM) vs. } 2.63 \pm 0.77 \text { (SEM) } \mathrm{mg} / \mathrm{L} \text { respectively, } \mathrm{P}=\mathrm{NS} \text { ]. } \\
\text { On the other hand, SCF group showed trends of lower Myeloperoxidase } \\
\text { and Arginine levels at baseline as compared to } \mathrm{SCF} \text { free control } \\
\text { group. Here too, the comparisons did not reach statistical significance } \\
\text { [Myeloperoxidase: } 16.9 \pm 2.3 \text { (SEM) vs. } 24.9 \pm 4.8 \text { (SEM) ng/mL respectively, } \\
\mathrm{P}=\mathrm{NS} \text {; Arginine: } 99.8 \pm 4.2 \text { (SEM) vs. } 108.7 \pm 5.5 \text { (SEM) } \mu \mathrm{M} \text { respectively, } \\
\mathrm{P}=\mathrm{NS} \text { ]. } \\
\text { While MDA, ADMA and SDMA levels were seen to be comparable amongst } \\
\text { SCF and control groups [MDA: } 0.19 \pm 0.08 \text { (SEM) vs. } 0.19 \pm 0.05 \text { (SEM) ng/ } \\
\mathrm{mL} \text { respectively, P=NS; ADMA: } 0.57 \pm 0.01 \text { (SEM) vs. } 0.59 \pm 0.01 \text { (SEM) } \mu \mathrm{M} \\
\text { respectively, } \mathrm{P}=\mathrm{NS} \text {; SDMA: } 0.55 \pm 0.01 \text { (SEM) vs. } 0.53 \pm 0.01 \text { (SEM) } \mu \mathrm{M} \\
\text { respectively, } \mathrm{P}=\mathrm{NS} \text { ]. }\end{array}$ \\
\hline
\end{tabular}

$\begin{array}{lll}\begin{array}{l}\text { Yoon et al., } \\ 2012^{29}\end{array} & \begin{array}{l}\text { Homocysteine; } \\ \text { CRP; Fibrinogen }\end{array} & \begin{array}{l}\text { Korea, Asian (44/41) } \\ \text { Ancestry }\end{array} \\ & & \\ & & \\ \text { Yucel et } & \text { Nitric Oxide; } & \text { Turkey, Middle } 80(50 / 30) \\ \text { al., 2012 } & \text { Homocysteine; } & \text { Eastern Ancestry } \\ & \text { ADMA } & \end{array}$

\begin{tabular}{|c|c|c|c|}
\hline $\begin{array}{l}\text { Tasolar et } \\
\text { al., } 2013^{31}\end{array}$ & Nitric Oxide & $\begin{array}{l}\text { Turkey, Middle } \\
\text { Eastern Ancestry }\end{array}$ & $39(22 / 17)$ \\
\hline $\begin{array}{l}\text { Yurtdas et } \\
\text { al., } 2013^{32}\end{array}$ & Homocysteine & $\begin{array}{l}\text { Turkey, Middle } \\
\text { Eastern Ancestry }\end{array}$ & $82(41 / 41)$ \\
\hline $\begin{array}{l}\text { Gupta et } \\
\text { al., } 2014^{11}\end{array}$ & Nitric Oxide & $\begin{array}{l}\text { India, Asian } \\
\text { Indian Ancestry }\end{array}$ & $227(27 / 200$ \\
\hline $\begin{array}{l}\text { Tang et al., } \\
2014^{17}\end{array}$ & $\begin{array}{l}\text { Homocysteine; } \\
\text { Folate; Fibrinogen; } \\
\text { Uric acid }\end{array}$ & $\begin{array}{l}\text { China, Asian } \\
\text { Ancestry }\end{array}$ & $75(50 / 25)$ \\
\hline
\end{tabular}

\begin{tabular}{|c|c|c|c|}
\hline $\begin{array}{l}\text { Chen et } \\
\text { al., } 2015^{33}\end{array}$ & $\begin{array}{l}\text { Nitric Oxide; } \\
\text { Endothelin-1 }\end{array}$ & $\begin{array}{l}\text { China, Asian } \\
\text { Ancestry }\end{array}$ & $56(36 / 20)$ \\
\hline $\begin{array}{l}\text { Shi et al., } \\
2015^{16}\end{array}$ & Inteleukin-10 & $\begin{array}{l}\text { China, Asian } \\
\text { Ancestry }\end{array}$ & $250(41 / 209)$ \\
\hline
\end{tabular}

SCF group had statistically higher Hcy levels as compared to SCF free control group (9.30 \pm 4.89 vs. $7.34 \pm 2.44 \mu \mathrm{mol} / \mathrm{L}$ respectively, $\mathrm{P}=0.031$ ). On the other hand, SCF group showed trends of higher CRP and fibrinogen levels as compared to SCF free control group. The comparisons however did not reach statistical significance (CRP: $0.57 \pm 1.01$ vs. $0.16 \pm 0.18 \mathrm{mg} / \mathrm{dL}$ respectively, $\mathrm{P}=\mathrm{NS}$; Fibrinogen $=277.49 \pm 83.18$ vs. $258.22 \pm 59.12 \mu \mathrm{g} / \mathrm{mL}$ respectively, $\mathrm{P}=\mathrm{NS}$ ).

SCF group had statistically lower NO levels as compared to SCF free control group ( $11.4 \pm 6$ vs. $16.1 \pm 9 \mu \mathrm{mol} / \mathrm{L}$ respectively, $\mathrm{P}=0.02)$.

On the other hand, SCF group had statistically higher Hcy and ADMA levels as compared to SCF free control group (Hcy: $12.4 \pm 5$ vs. $9.8 \pm 2 \mu \mathrm{mol} / \mathrm{L}$ respectively, $\mathrm{P}=0.03$; $\mathrm{ADMA}$ : 0.9 $\pm 0.3,0.7 \pm 0.3 \mu \mathrm{M}$ respectively, $\mathrm{P}=0.01$ ).

SCF group had statistically lower NO levels at baseline as compared to SCF free control group ( $32.58 \pm 21.36$ vs. $48.16 \pm 24.35 \mathrm{pg} / \mathrm{mL}$ respectively). NO levels increased in both the groups after exercise $(25.02 \pm 17.69$ vs. 44.13 $\pm 17.39 \mu \mathrm{mol} / \mathrm{L}$ respectively).

SCF group had statistically higher Hcy levels as compared to SCF free control group ( $14.9 \pm 4.0$ vs. $6.5 \pm 4.8 \mu \mathrm{mol} / \mathrm{L}$ respectively, $\mathrm{P}<0.0001)$.

SCF group had statistically higher NO levels as compared to SCF free control group (144.51 \pm 43.25 vs. $129.64 \pm 29.47 \mu \mathrm{mol} / \mathrm{L}$ respectively, $\mathrm{P}=0.022$ ).

SCF group had statistically higher Hcy and uric acid levels as compared to SCF free control group (Hcy: $13.30 \pm 4.51$ vs. $9.95 \pm 3.55 \mu \mathrm{mol} / \mathrm{L}$ respectively, $\mathrm{P}<0.01$; Uric acid: $321.76 \pm 81.92$ vs. $275.40 \pm 58.85 \mu \mathrm{mol} / \mathrm{L}$ respectively, $\mathrm{P}=0.02)$.

On the other hand, SCF group had statistically lower folate levels as compared to SCF free control group $(12.59 \pm 2.75$ vs. $14.11 \pm 3.39 \mathrm{ng} / \mathrm{mL}$ respectively, $\mathrm{P}<0.05)$.

While, SCF group showed trends of higher fibrinogen levels as compared to SCF free control group. The comparison however did not reach statistical significance (3.44 \pm 0.95 vs. $3.23 \pm 0.54 \mathrm{~g} / \mathrm{L}$ respectively, $\mathrm{P}=\mathrm{NS}$ ).

SCF group had statistically lower NO levels as compared to SCF free control group $(23.96 \pm 4.51$ vs. $39.63 \pm 3.82 \mu \mathrm{mol} / \mathrm{L}$ respectively, $\mathrm{P}<0.001)$. On the other hand, SCF group had statistically higher endothelin-1 levels at baseline as compared to SCF free control group $(12.49 \pm 1.43$ vs. $4.91 \pm 1.36$ $\mathrm{pg} / \mathrm{mL}$ respectively, $\mathrm{P}<0.001)$.

SCF group had statistically lower interleukin-10 levels as compared to SCF free control group ( $1.89 \pm 0.18$ vs. $2.01 \pm 0.22 \mathrm{ng} / \mathrm{L}$ respectively, $\mathrm{P}=0.001)$.

SCF: Slow coronary flow; NO: Nitric Oxide; Hcy: Homocysteine; MDA: Malondialdehyde; CRP: C-reactive protein; ESD: Erythrocyte superoxide dismutase; ADMA: Asymmetric dimethylarginine; SDMA: Symmetric dimethylarginine; ICAM-1: Intracellular adhesion molecule-1; VCAM-1: Vascular cell adhesion molecule-1; NS: Non significant; SEM: Standard error of mean.

SCF assessment tool used in all above included studies was thrombolysis in myocardial infarction-frame count (TIMI-FC). 
Rai H. et al: Genetic and biochemical basis of slow coronary flow

Explor Res Hypothesis Med

\begin{tabular}{|c|c|c|c|c|c|c|c|c|c|c|c|}
\hline Study or Subgroup & \multicolumn{2}{|c|}{ Case } & \multicolumn{2}{|c|}{ Control } & \multicolumn{3}{|c|}{ Odds Ratio } & \multicolumn{4}{|c|}{$\begin{array}{c}\text { Odds Ratio } \\
\text { M-H, Fixed, } 95 \% \mathrm{Cl} \\
\end{array}$} \\
\hline Caglayan et al. & 49 & 66 & 11 & 19 & $44.2 \%$ & $2.10[0.72,6.08]$ & 2009 & & & G & \\
\hline Gupta et al. & 13 & 27 & 45 & 200 & $55.8 \%$ & $3.20[1.40,7.30]$ & 2014 & & & & \\
\hline Total $(95 \% \mathrm{Cl})$ & & 93 & & 219 & $100.0 \%$ & $2.71[1.41,5.20]$ & & & & & \\
\hline Total events & 62 & & 56 & & & & & & & & \\
\hline $\begin{array}{l}\text { Heterogeneity: } \mathrm{Chi}^{2} \\
\text { Test for overall effec }\end{array}$ & $\begin{array}{l}0.38, \mathrm{df}= \\
Z=3.00\end{array}$ & $\begin{array}{l}1(P= \\
P=0.0\end{array}$ & $\begin{array}{l}0.54) ; 1^{2}= \\
003)\end{array}$ & & & & & 0.1 & $\begin{array}{cc}1 & 1 \\
\text { Decreased risk of } \mathrm{SCF}\end{array}$ & $\begin{array}{c}1 \\
1 \\
\text { Increased }\end{array}$ & $\begin{array}{r}\frac{1}{5} \\
\text { I risk of } \mathrm{SCF}\end{array}$ \\
\hline
\end{tabular}

A

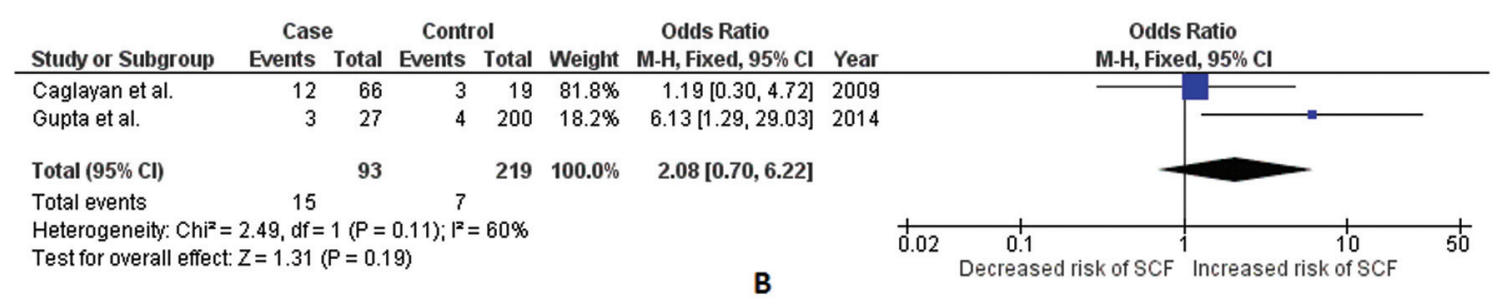

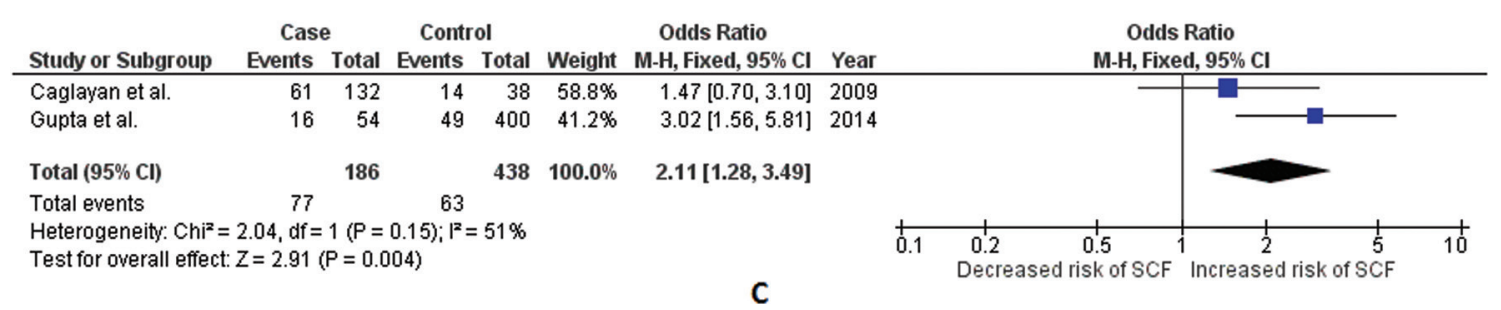

Fig. 3. Forest plots depicting meta-analysis results for NOS3 $849 \mathrm{G}>\mathrm{T}$ polymorphism (rs1799983) and its association with slow coronary flow (SCF). A: Effect size estimation using dominant genetic model (TT+GT vs. GG); B: Effect size estimation using recessive genetic model (TT vs. GT+GG); C: Effect size estimation using allelic genetic model (allele T vs. allele G). Quantitative synthesis for all three genetic models was done using fixed effects for analysis.

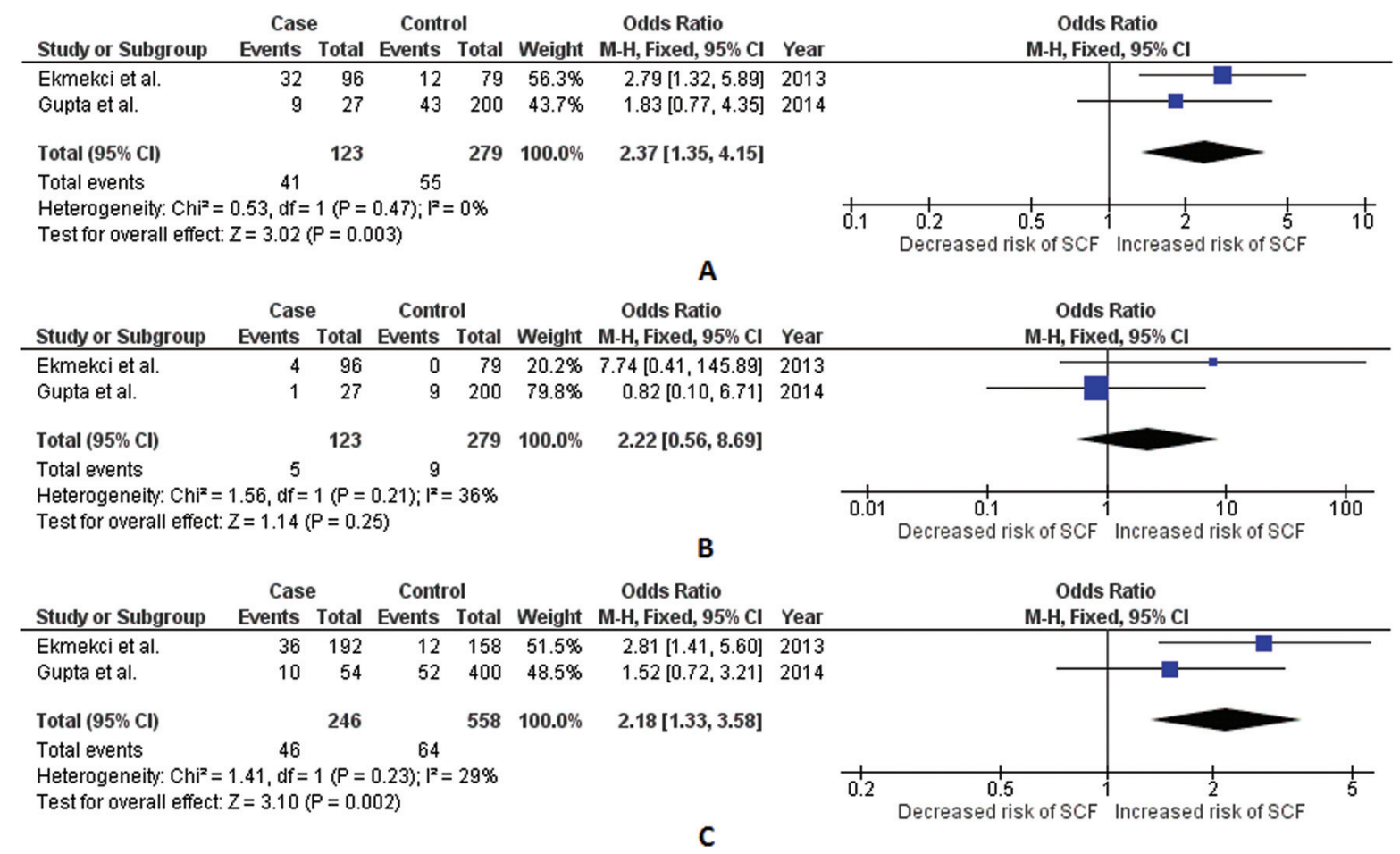

Fig. 4. Forest plots depicting meta-analysis results for NOS3 4b/a 27bp VNTR polymorphism and its association with slow coronary flow (SCF). A: Effect size estimation using dominant genetic model ( $a / a+a / b$ vs. b/b); B: Effect size estimation using recessive genetic model (a/a vs. a/b + b/b); $C$ : Effect size estimation using allelic genetic model (allele a vs. allele b). Quantitative synthesis for all three genetic models was done using fixed effects for analysis. 


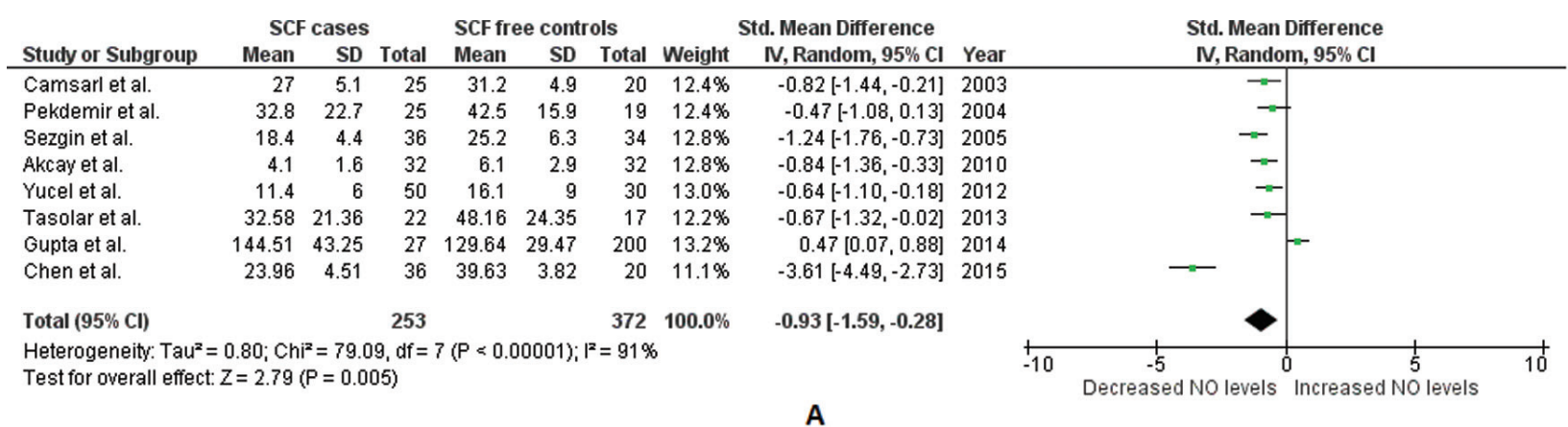

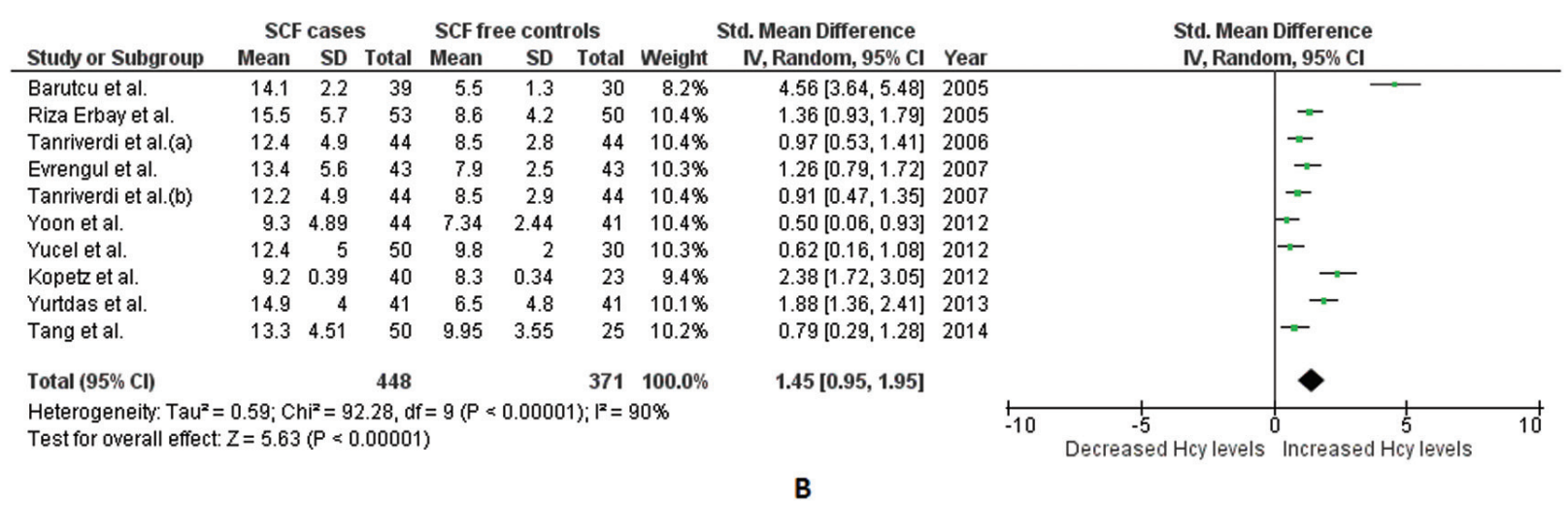

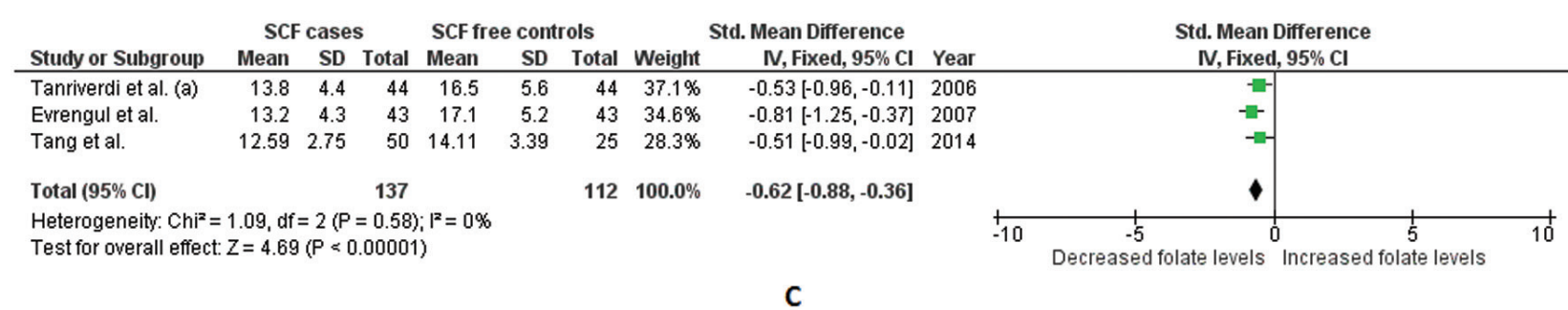

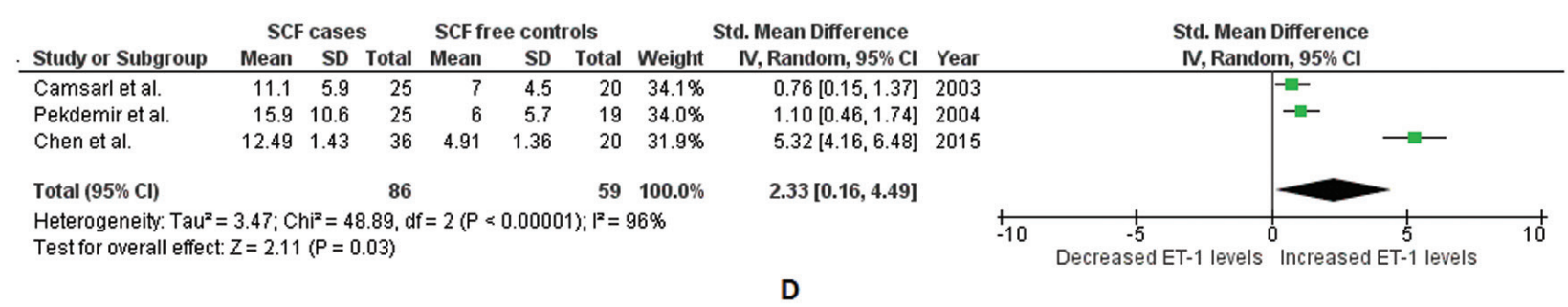

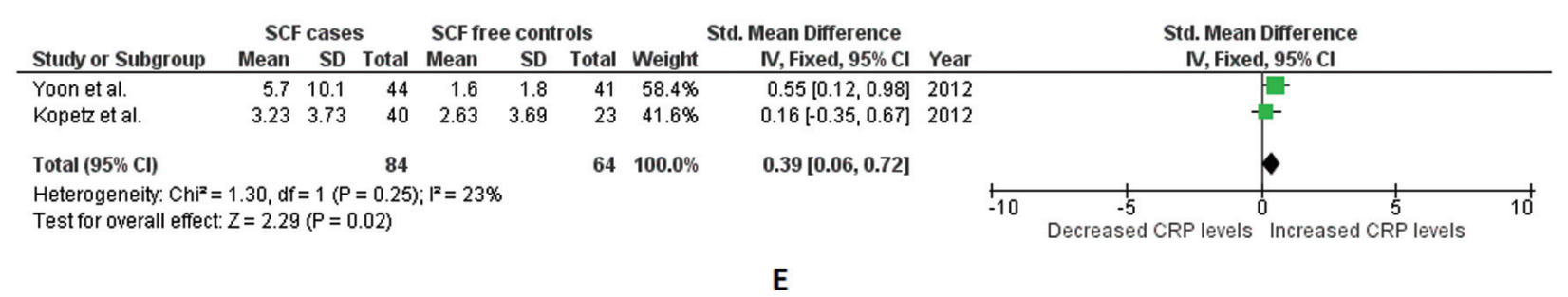

Fig. 5. Forest plots depicting meta-analysis results for possible biochemical correlates of slow coronary flow (SCF). A: Effect size estimated for serum nitric oxide (NO) levels as a correlate for SCF (NO values in $\mu \mathrm{mol} / \mathrm{L}$ ); B: Effect size estimated for serum homocysteine (Hcy) levels as a correlate for SCF (Hcy values in $\mu \mathrm{mol} / \mathrm{L}$ ); C: Effect size estimated for serum folate levels as a correlate for SCF (folate values in $\mathrm{ng} / \mathrm{mL}$ ); $\mathrm{D}$ : Effect size estimated for serum endothelin-1 (ET-1) levels as a correlate for SCF (ET-1 values in $\mathrm{pg} / \mathrm{mL}$ ); E: Effect size estimated for serum C-reactive protein (CRP) levels as a correlate for SCF (CRP values in $\mathrm{mg} / \mathrm{L})$. 
allele ('a' allele) has been shown to be associated with CAD worldwide, as well as individually among several ethnic subgroups in a recently published meta-analysis. ${ }^{39}$ Although a clear-cut association between the NOS $34 \mathrm{~b} / \mathrm{a}$ VNTR polymorphism and SCF is seen in the pooled results of our meta-analysis, as well as individually in the two included studies, a clear scientific explanation behind the observed association is lacking. ${ }^{11,14}$ There are conflicting reports published about the role of this polymorphic variant in NO pathway activity. Carriage of the 'a' allele has been shown as associated with reduced plasma NO levels, coupled with reduced protein expression. ${ }^{46}$ On the other hand, lack of its association with NO levels or protein expression has also been documented by several researchers. ${ }^{47-49}$ Even if $4 \mathrm{~b} / \mathrm{a}$ VNTR is not functional by itself, it lies in the intron region and has been reported to act in linkage disequilibrium with other regulatory regions and other functional gene variants of the NOS3 gene and thus has potential to impart additional risk for several diseases. ${ }^{50}$

We came across a study that had tested the association of $I L-10$ $592 \mathrm{~A}>\mathrm{C}$, rs 1800872 with SCF among a cohort with Chinese ethnicity. ${ }^{16}$ IL-10 is known to be a multifunctional anti-inflammatory cytokine. It is known to down-regulate cell-mediated immunity, as well as cytotoxic inflammatory responses. ${ }^{51,52}$ It is well known that $50 \square 75 \%$ of the variation in IL-10 production is controlled genetically ${ }^{53,54} I L-6-819 \mathrm{C}>\mathrm{T}$ is the other common SNP in the $I L-6$ gene, and it shows tight linkage disequilibrium with $I L-10592 \mathrm{~A}>\mathrm{C} .{ }^{55,56}$ Notably, regardless of their genetic composition, lower means levels of serum IL-10 were seen in the SCF group as compared to that in controls. ${ }^{16}$

SCF patients with AA genotype was seen to have even lower serum IL-10 levels than the patients carrying only one or none of ' $\mathrm{A}$ ' (major) allele. ${ }^{16} \mathrm{Shi}$ and colleagues reported a strong association of the 'A' allele itself and of its carriers with SCF, which supports the hypothesis that low-grade inflammation plays a role in the pathophysiology of SCF. The area near position -592 contains putative binding sites for IL-6 and signal transducer and activator of transcription 1 (STAT-1), which are important signaling pathway molecules that initiate the inflammatory process. ${ }^{57}$ Lower plasma IL-10 levels in 'A' allele carriers may thus facilitate the pro-inflammatory cytokines initiating and maintaining the SCF phenomenon.

Another study among a cohort of ethnic Chinese individuals tested MTHFR 677C $>\mathrm{T}$ (rs 1801133) for its association with SCF. ${ }^{17}$ The researchers were able to deduce a strong association with the condition and the carriers of the ' $\mathrm{T}$ ' (minor) allele, who had higher odds of developing SCF. ${ }^{17}$ The MTHFR gene encodes for the enzyme called MTHFR, which is a rate-limiting enzyme of the methyl cycle. ${ }^{58}$ MTHFR catalyzes the conversion of 5,10-methylenetetrahydrofolate to 5-methyltetrahydrofolate (a co-substrate for homocysteine re-methylation) to methionine. Genotypes of the ' $\mathrm{T}$ ' (minor) allele are known to have lower MTHFR activity, which translates to higher levels of plasma homocysteine levels, a condition called as hyperhomocysteinemia. Hyperhomocysteinemia is recognized as an independent risk factor for intracoronary thrombosis and microalbuminuria (a strong predictor for future cardiovascular events). ${ }^{59,60}$

Baseline plasma Hcy levels have been reported to be higher in patients with SCF as compared to SCF-free controls. ${ }^{32}$ Hcy levels are also associated with development of electrocardiographically detectible ischemia during exercise in SCF patients. ${ }^{32}$ Tang and colleagues also reported that carriers of the ' $\mathrm{T}$ ' (minor) have markedly higher levels of plasma Hcy, both in SCF and control cohorts, the mean levels of which were much higher in SCF cases. ${ }^{17}$ It is plausible that microvascular dysfunction caused by higher levels of plasma Hcy in carriers of the ' $\mathrm{T}$ ' (minor) allele is one of the major factors leading to SCF, which translated to the strong as- sociation observed in the study by Tang et al. ${ }^{17,61}$ The detailed mechanism of how Hcy causes microvascular dysfunction is still scarcely known and warrants further in vivo studies.

Gazi and colleagues tested the $469 \mathrm{G}>\mathrm{A}$, rs5498 polymorphism of the ICAMI gene for its involvement in SCF, amongst a cohort of ethnic Turkish individuals. ${ }^{13}$ ICAM1 is an important immunoglobulin and it plays several important roles in the intricacies of endothelial functions. ICAM1, which is one of the most studied immunoglobulin, is released in the human body from endothelial cells, small muscle cells, macrophages and lymphocytes. ${ }^{62,63}$ It induces leukocyte adhesion and their transmigration to vascular basal membranes, making it an important factor both for inflammation and atherosclerosis. ${ }^{62,63}$ The ICAMI $469 \mathrm{G}>\mathrm{A}$, rs5498 polymorphism (also known as $\mathrm{K} 469 \mathrm{E}$ polymorphism) is involved in the increase of serum levels and functions of the resultant ICAM1 molecule and has been shown to be independently related to the initiation and progression of atherosclerosis. ${ }^{64,65}$

Since the role of $469 \mathrm{G}>\mathrm{A}$, rs 5498 polymorphism of the ICAMI gene in various inflammatory processes has been demonstrated, and its role in endothelial dysfunction is plausible, it is an ideal SNP to be investigated for SCF. Its role in SCF was thus investigated in a Turkish cohort, and the results showed a strong association with the condition. ${ }^{13}$ Carriers of the ' $G$ ' (major) allele were seen to carry a higher risk for developing SCF, conversely the ' $\mathrm{A}$ ' (minor) allele was deduced to be a protective factor against SCF. ${ }^{13}$ The study revealing these findings, however, was small and the results need to be validated by larger investigations of various groups subjects belonging to different ethnicities.

Studies investigating several other SNPs were also reviewed for this manuscript. There were 2 published studies for the $A C E \mathrm{I} / \mathrm{D}$, rs1799752 polymorphism, both conducted on subjects of Turkish descent. The study from Yalcin and colleagues showed association in recessive and allelic genetic models, suggesting a deletion homozygote (DD) genotype and that the ' $\mathrm{D}$ ' allele imparts protection against SCF. ${ }^{15}$ Since the $95 \% \mathrm{CI}$ range of the OR attained for the aforementioned genetic models was wide, and the second study in the quantitative synthesis showed clear lack of association, an effect on the pooled results was ruled out, which ultimately reflected non-association in all three genetic models $(p=0.19-0.33) .{ }^{15,18}$ (Fig. S2A-C) One study each was available for this review for AGT $207 \mathrm{C}>\mathrm{T}$ (rs4762): PAI-1 4G/5G, (rs1799889) and AGTR1 $1166 \mathrm{~A}>\mathrm{C}$ (rs5186) polymorphisms. ${ }^{13,15,18}$ However, all were negative studies, displaying lack of associations with SCF $(p>0.05)$ and they did not have much to contribute to the problem at hand. (Table 1)

\section{Biochemical correlates of SCF}

We deduced a few strong biochemical correlates of SCF, with the present meta-analysis and review displaying a correlation that was either positive (Hcy, ET-1, ICAM, VCAM, E-selectin and uric acid) or a negative (NO, folate, glutathione, erythrocyte catalase and IL-10). (Fig. 5A-D and Table 2)

The underlying mechanisms of Hcy and NO leading to impaired FMD and promoting the SFC phenomenon are interlinked. Elevated levels of Hcy has been associated with impaired flowmediated endothelium-dependent vasodilatation in children, as well as in adults. ${ }^{66,67}$ The process of damage in endothelium in cases with hyperhomocysteinemia has been explained as a result of impairment of the basal production of $\mathrm{NO}$ brought about by the emergence of biochemically active hydrogen peroxide $\left(\mathrm{H}_{2} \mathrm{O}_{2}\right)$, superoxide anion $\left(\mathrm{O}_{2}-\right)$ and hydroxyl radical (HO). ${ }^{67}$ In summary, chronic high levels of Hcy result in oxidative stress caused by de- 
pletion of bioactive NO levels. ${ }^{68}$ Elevated plasma levels of Hcy in hyperhomocysteinemic individuals may thus lead to impaired FMD, which is a common phenomenon seen among SCF cases. ${ }^{67}$ The present meta-analysis therefore, befittingly shows this positive correlation between Hcy and SCF. (Fig. 5B)

Lower plasma NO levels and its reduced bioactivity have already been shown to be independent risk factors for endothelial dysfunction and also to be associated with SCF. ${ }^{19}$ Our meta-analysis results attest to the role of low plasma $\mathrm{NO}$ concentrations in the pathogenesis of SCF. (Fig. 5A)

Scientific evidence also points towards a strong association between hyperhomocystenemia and inadequate vitamin intake leading to lower plasma concentrations of vitamins, as is especially seen with vitamin B12 and folate levels. ${ }^{69,70}$ All three included studies reporting differences in folate levels between the SCF and controls groups thus displayed such results (i.e. lower folate levels among the SCF cases as compared to the controls). ${ }^{17,24,25}$ This correlation was also attested to by the present meta-analysis. (Fig. 5C)

ET-1 is a vasoconstrictor peptide, known to increase coronary vascular resistance, which in turn contributes to progression of atherosclerosis. Plasma concentration of ET-1 is also increased in the event of an endothelial injury and among syndrome X patients (patients having chest pain but angiographically patent coronary arteries). ${ }^{71,72}$ Befittingly, higher ET-1 levels have been consistently shown to be associated with SCF in several published studies, as well as in the present meta-analysis. ${ }^{19,20,33}$ (Fig. 5D)

Other biomarkers like ICAM, VCAM, E-selectin and uric acid have been shown to be positively correlated, while glutathione, erythrocyte catalase and IL-10 have been shown to be negatively correlated with SCF through various single published studies, with modest sample sizes. ${ }^{16,17,26,27,34}$ (Table 2) More studies, with larger sample sizes are warranted, however, to definitively assess the role of these correlates in the pathophysiology of SCF.

Considering the data published on the subject so far, it would be fair to say that SCF may very well have a genetic component as well as several biochemical correlates. However, it can be argued the SCF is a multifactorial disorder and that the role of other previously described etiological factors like small vessel diameter, presence of some degree of coronary microvascular endothelial dysfunction (possibly brought about by these biochemical correlates) and diffused stenosis can prove substantial in the development of SCF. Genetic composition of an individual only seems to an additional factor for increasing the odds of developing the disease. The relationship of SCF with several of its biochemical correlates seems not so straight forward. Further studies are warranted to evaluate each and discern if any individual biochemical entity is indeed a precursor for SCF or is differentially released as a consequence of SCF.

It is interesting that most of the published studies on the subject have originated from either Asian/Asian-Indian cohorts, who are known to have smaller vessel diameter, or cohorts of Middleeastern ethnicity (specifically of Turkish descent). ${ }^{10-27,29-34,73}$ This profile may be due to the restricted marriage traditions of these ethnic groups, specifically endogamy (the custom of marrying only within the limits of a local community, clan, or tribe) and/or (cousin marriages), both of which are known to exacerbate the effect of genetically transmitted disorders.

Most of the statistical methods used for the evaluation of existing publication bias are sensitive to heterogeneity, however the Begg's funnel plot is one of the most widely used tools. ${ }^{38}$ We found no evidence of significant publication bias in our tested groups; yet, its presence can never be fully ruled out, at least not while dealing with non-randomized observational studies. Our sensitivity analysis, however, indicated that our results obtained for NO and Hcy were robust.

\section{Limitations}

Primarily, the lack of studies limited our statistical approach for the present meta-analysis in several ways. (1) Since, all the groups constructed for polymorphic variants had only 2 studies each (and some biochemical correlates like Fib, ESD and ADMA), we had to use a fixed effects model (Mantel-Haenszel method) for OR calculation. As such, we did not have the choice to use either a random (DerSimonian-Laird method) or fixed effects model (MantelHaenszel method), which otherwise would have been a decision based on the inherent heterogeneity of the group (please see the process described in Materials and Methods section). ${ }^{36,37}$ Since, all the groups constructed for polymorphic variants had only 2 studies each, the results of the $\mathrm{Q}$ test were unable to guide our approach. We, therefore, had to use a fixed effects model in these groups, which may have not been the ideal approach. ${ }^{36}$ (2) Presence of publication bias among the study groups is best estimated by an Begg's funnel test. ${ }^{38}$ These estimates are usually calculated in study groups with $\geq 3$ studies. Since we had only two such groups, with $\geq 3$ studies (this was only done for the biochemical correlates $\mathrm{NO}$ and Hcy), the publication bias assessment could not be done for all other groups. (3) Lack of sufficient studies in these groups also prevented us from performing sensitivity analysis (this was only done for the biochemical correlates $\mathrm{NO}$ and Hcy).

\section{Conclusions}

The results of the present meta-analysis and review suggest the presence of a strong genetic component for SCF. So far, several SNPs residing in several genes seem to be associated with SCF (notably rs1799983, NOS3 -4b/a 27bp VNTR, rs1800872, rs1801133 and rs5498). We also noted the presence of several positively associated biochemical correlates (notably Hcy, ET-1 and CRP) as well as negatively associated biochemical correlates of SCF (notably NO and folate). Published studies on this subject are, however, few, small and sporadic; therefore, several large and statistically-powered studies are warranted to substantiate our findings. Our presented results, nonetheless, could be assessed for their clinical implication, especially with respect to screening and early detection of SCF.

\section{Conflict of interest}

The authors have no conflict of interest related to this publication.

\section{Author contributions}

Designing the study (HR), developing the methodology (HR), collecting data (HR), performing the analysis (HR), writing the manuscript (HR), interpretation of results (NS), writing and subsequent revisions of the manuscript (NS).

\section{Supplementary information}

Supplementary material for this article is available at https://doi.org/ 10.14218/ERHM.2016.00010. 
Fig. S1. Forest plots depicting meta-analysis results for NOS3 $786 \mathrm{~T}>\mathrm{C}$ polymorphism (rs2070744) and its association with slow coronary flow (SCF).

Fig. S2. Forest plots depicting meta-analysis results for ACE I/D polymorphism (rs1799752) and its association with slow coronary flow (SCF).

Fig. S3. Forest plots depicting statistically non-significant metaanalysis results for several other tested possible biochemical correlates of slow coronary flow $(\mathrm{SCF})$.

Fig. S4. Publication bias assessment among groups of studies investigating biochemical correlates of slow coronary flow (SCF) yielding significant results.

\section{References}

[1] Beltrame JF, Limaye SB, Wuttke RD, Horowitz JD. Coronary hemodynamic and metabolic studies of the coronary slow flow phenomenon. Am Heart J 2003;146(1):84-90. doi:10.1016/s0002-8703(03)001248.

[2] Tambe AA, Demany MA, Zimmerman HA, Mascarenhas E. Angina pectoris and slow flow velocity of dye in coronary arteries - a new angiographic finding. Am Heart J 1972;84(1):66-71. doi:10.1016/00028703(72)90307-9.

[3] Mangieri E, Macchiarelli G, Ciavolella M, Barilla F, Avella A, Martinotti $A$, et al. Slow coronary flow: clinical and histopathological features in patients with otherwise normal epicardial coronary arteries. Cathet Cardiovasc Diagn 1996;37(4):375-381. doi:10.1002/(SICI)10970304(199604)37:4<375::AID-CCD7>3.0.CO;2-8.

[4] Beltrame JF, Limaye SB, Horowitz JD. The coronary slow flow phenomenon-a new coronary microvascular disorder. Cardiology 2002;97(4):197-202. doi:10.1159/000063121.

[5] Gibson CM, Cannon CP, Daley WL, Dodge JT Jr, Alexander B Jr, Marble $\mathrm{SJ}$, et al. TIMI frame count: a quantitative method of assessing coronary artery flow. Circulation 1996;93(5):879-888. doi:10.1161/01. CIR.93.5.879.

[6] Sezgin AT, Sigirci A, Barutcu I, Topal E, Sezgin N, Ozdemir R, et al. Vascular endothelial function in patients with slow coronary flow. Coron Artery Dis 2003;14(2):155-161. doi:10.1097/01. mca.0000062039.09396.f9.

[7] Pekdemir H, Cin VG, Cicek D, Camsari A, Akkus N, Doven O, et al. Slow coronary flow may be a sign of diffuse atherosclerosis. Contribution of FFR and IVUS. Acta Cardiol 2004;59(2):127-133. doi:10.2143/ ac.59.2.2005166.

[8] Gullu H, Erdogan D, Caliskan M, Tok D, Yildirim E, Ulus T, et al. Interrelationship between noninvasive predictors of atherosclerosis: transthoracic coronary flow reserve, flow-mediated dilation, carotid intima-media thickness, aortic stiffness, aortic distensibility, elastic modulus, and brachial artery diameter. Echocardiography 2006;23(10):835-842. doi:10.1111/j.1540-8175.2006.00342.x.

[9] Ari H, Ari S, Erdogan E, Tiryakioglu O, Huysal K, Koca V, et al. The effects of endothelial dysfunction and inflammation on slow coronary flow. Turk Kardiyol Dern Ars 2010;38(5):327-333.

[10] Caglayan AO, Kalay N, Saatci C, Yalcyn A, Akalyn H, Dundar M. Lack of association between the Glu298Asp polymorphism of endothelial nitric oxide synthase and slow coronary flow in the Turkish population. Can J Cardiol 2009;25(3):e69-e72. doi:10.1016/S0828282X(09)70044-3.

[11] Gupta MD, Akkarappatty C, Girish MP, Kumar R, Rain M, Tyagi S, et al. Association between the Glu298Asp and 4b/4a polymorphisms of endothelial nitric oxide synthase and coronary slow flow in the North Indian population. Coron Artery Dis 2014;25(3):192-197. doi:10.1097/mca.0000000000000093.

[12] Nurkalem Z, Tangurek B, Zencirci E, Alper AT, Aksu H, Erer B, et al. Endothelial nitric oxide synthase gene (T-786C) polymorphism in patients with slow coronary flow. Coron Artery Dis 2008;19(2):85-88.
doi:10.1097/MCA.0b013e3282f52940.

[13] Gazi E, Barutcu A, Altun B, Temiz A, Bekler A, Urfali M, et al. Intercellular adhesion molecule-1 K469E and angiotensinogen T207M polymorphisms in coronary slow flow. Med Princ Pract 2014;23(4):346350. doi:10.1159/000363451.

[14] Ekmekci A, Gungor B, Ozcan KS, Abaci N, Ilhan E, Ekmekci SS, et al. Evaluation of coronary microvascular function and nitric oxide synthase intron $4 \mathrm{a} / \mathrm{b}$ polymorphism in patients with coronary slow flow. Coron Artery Dis 2013;24(6):461-467. doi:10.1097/ MCA.0b013e328363258c.

[15] Yalcin AA, Kalay N, Caglayan AO, Kayaalti F, Duran M, Ozdogru I, et al. The relationship between slow coronary flow and angiotensin converting enzyme and ATIIR1 gene polymorphisms. J Natl Med Assoc 2009;101(1):40-45. doi:10.1016/S0027-9684(15)30810-5.

[16] Shi GL, Cai XX, Su YM, Chen C, Deng XT, Pan HY, et al. Interleukin-10 promotor $-592 \mathrm{~A} / \mathrm{C}$ polymorphism is associated with slow coronary flow in Han Chinese. Int J Clin Exp Pathol 2015;8(4):4091-4098.

[17] Tang O, Wu J, Qin F. Relationship between methylenetetrahydrofolate reductase gene polymorphism and the coronary slow flow phenomenon. Coron Artery Dis 2014;25(8):653-657. doi:10.1097/ mca.0000000000000151.

[18] Gazi E, Temiz A, Altun B, Barutcu A, Silan F, Colkesen Y, et al. Endothelial function and germ-line ACE I/D, eNOS and PAI-1 gene profiles in patients with coronary slow flow in the Canakkale population: multiple thrombophilic gene profiles in coronary slow flow. Cardiovasc $J$ Afr 2014;25(1):9-14. doi:10.5830/cvja-2013-083.

[19] Camsarl A, Pekdemir H, Cicek D, Polat G, Akkus MN, Doven O, et al. Endothelin-1 and nitric oxide concentrations and their response to exercise in patients with slow coronary flow. Circ J 2003;67(12):10221028. doi:10.1253/circj.67.1022.

[20] Pekdemir H, Cicek D, Camsari A, Akkus MN, Cin VG, Doven O, et al. The relationship between plasma endothelin-1, nitric oxide levels, and heart rate variability in patients with coronary slow flow. Ann Noninvasive Electrocardiol 2004;9(1):24-33. doi:10.1111/j.1542 474X.2004.91522.x.

[21] Sezgin N, Barutcu I, Sezgin AT, Gullu H, Turkmen M, Esen AM, et al. Plasma nitric oxide level and its role in slow coronary flow phenomenon. Int Heart J 2005;46(3):373-382. doi:10.1536/ihj.46.373.

[22] Barutcu I, Sezgin AT, Sezgin N, Gullu H, Esen AM, Topal E, et al. Elevated plasma homocysteine level in slow coronary flow. Int J Cardiol 2005;101(1):143-145. doi:10.1016/j.ijcard.2004.01.030.

[23] Riza Erbay A, Turhan H, Yasar AS, Ayaz S, Sahin O, Senen K, et al. Elevated level of plasma homocysteine in patients with slow coronary flow. Int J Cardiol 2005;102(3):419-423. doi:10.1016/j.ijcard.2004.05.064.

[24] Tanriverdi H, Evrengul H, Tanriverdi S, Kuru O, Seleci D, Enli Y, et al. Carotid intima-media thickness in coronary slow flow: relationship with plasma homocysteine levels. Coron Artery Dis 2006;17(4):331337.

[25] Evrengul H, Tanriverdi H, Kuru O, Enli Y, Yuksel D, Kilic A, et al. Elevated homocysteine levels in patients with slow coronary flow: relationship with Helicobacter pylori infection. Helicobacter 2007;12(4):298-305. doi:10.1111/j.1523-5378.2007.00505.x.

[26] Tanriverdi H, Evrengul H, Enli Y, Kuru O, Seleci D, Tanriverdi S, et al. Effect of homocysteine-induced oxidative stress on endothelial function in coronary slow-flow. Cardiology 2007;107(4):313-320. doi:10.1159/000099068.

[27] Akcay A, Acar G, Kurutas E, Sokmen A, Atli Y, Nacar AB, et al. Beneficial effects of nebivolol treatment on oxidative stress parameters in patients with slow coronary flow. Turk Kardiyol Dern Ars 2010;38(4):244-249.

[28] Kopetz V, Kennedy J, Heresztyn T, Stafford I, Willoughby SR, Beltrame JF. Endothelial function, oxidative stress and inflammatory studies in chronic coronary slow flow phenomenon patients. Cardiology 2012;121(3):197-203. doi:10.1159/000336948.

[29] Yoon HJ, Jeong MH, Cho SH, Kim KH, Lee MG, Park KH, et al. Endothelial dysfunction and increased carotid intima-media thickness in the patients with slow coronary flow. J Korean Med Sci 2012;27(6):614618. doi:10.3346/jkms.2012.27.6.614.

[30] Yucel H, Ozaydin M, Dogan A, Erdogan D, Turker Y, Ceyhan BM, et al. Plasma concentrations of asymmetric dimethylarginine, nitric oxide 
and homocysteine in patients with slow coronary flow. Scand J Clin Lab Invest 2012;72(6):495-500. doi:10.3109/00365513.2012.69963 7.

[31] Tasolar H, Eyyupkoca F, Akturk E, Karakus Y, Cansel M, Yagmur J, et al. Endothelial nitric oxide synthase levels and their response to exercise in patients with slow coronary flow. Cardiovasc J Afr 2013;24(910):355-359. doi:10.5830/cvja-2013-072.

[32] Yurtdas M, Ozcan IT, Seyis AS, Camsari A, Cicek D. Plasma homocysteine is associated with ischemic findings without organic stenosis in patients with slow coronary flow. J Cardiol 2013;61(2):138-143. doi:10.1016/j.jjcc.2012.10.001.

[33] Chen Z, Chen X, Li S, Huo X, Fu X, Dong X. Nicorandil improves myocardial function by regulating plasma nitric oxide and endothelin-1 in coronary slow flow. Coron Artery Dis 2015;26(2):114-120. doi:10.1097/mca.0000000000000179.

[34] Turhan H. Increased plasma soluble adhesion molecules; ICAM-1, VCAM-1, and E-selectin levels in patients with slow coronary flow. Int J Cardiol 2006;108(2):224-230. doi:10.1016/j.ijcard.2005.05.008.

[35] Panic N, Leoncini E, de Belvis G, Ricciardi W, Boccia S. Evaluation of the endorsement of the preferred reporting items for systematic reviews and meta-analysis (PRISMA) statement on the quality of published systematic review and meta-analyses. PLoS One 2013;8(12):e83138. doi:10.1371/journal.pone.0083138.

[36] Mantel N, Haenszel W. Statistical aspects of the analysis of data from retrospective studies of disease. J Natl Cancer Inst 1959;22(4):719748. doi:10.1093/jnci/22.4.719.

[37] DerSimonian R, Laird N. Meta-analysis in clinical trials. Control Clin Trials 1986;7(3):177-188. doi:10.1016/0197-2456(86)90046-2.

[38] Begg CB, Mazumdar M. Operating characteristics of a rank correlation test for publication bias. Biometrics 1994;50(4):1088-1101. doi:10.2307/2533446.

[39] Rai H, Parveen F, Kumar S, Kapoor A, Sinha N. Association of endothelial nitric oxide synthase gene polymorphisms with coronary artery disease: an updated meta-analysis and systematic review. PLoS One 2014;9(11):e113363. doi:10.1371/journal.pone.0113363.

[40] Luo JQ, Wen JG, Zhou HH, Chen XP, Zhang W. Endothelial nitric oxide synthase gene G894T polymorphism and myocardial infarction: a meta-analysis of 34 studies involving 21,068 subjects. PLoS One 2014;9(1):e87196. doi:10.1371/journal.pone.0087196.

[41] Hingorani A, Jia H, Stevens P, Monteith M, Brown M. A common variant in Exon 7 of the endothelial constitutive nitric oxide synthase gene: identification by single strand conformation polymorphism analysis. Clin Science 1995;88(s32):21P. doi:10.1042/cs088021P.

[42] Philip I, Plantefeve G, Vuillaumier-Barrot S, Vicaut E, LeMarie C, Henrion D, et al. G894T polymorphism in the endothelial nitric oxide synthase gene is associated with an enhanced vascular responsiveness to phenylephrine. Circulation 1999;99(24):3096-3098. doi:10.1161/01.CIR.99.24.3096.

[43] Angeline T, Isabel W, Tsongalis GJ. Endothelial nitric oxide gene polymorphisms, nitric oxide production and coronary artery disease risk in a South Indian population. Exp Mol Pathol 2010;89(3):205-208. doi:10.1016/j.yexmp.2010.08.009.

[44] Yoshimura M, Yasue H, Nakayama M, Shimasaki Y, Sumida H, Sugiyama S, et al. A missense Glu298Asp variant in the endothelial nitric oxide synthase gene is associated with coronary spasm in the Japanese. Hum Genet 1998;103(1):65-69. doi:10.1007/s004390050785.

[45] Miyamoto $Y$, Saito Y, Kajiyama N, Yoshimura M, Shimasaki Y, Nakayama $\mathrm{M}$, et al. Endothelial nitric oxide synthase gene is positively associated with essential hypertension. Hypertension 1998;32(1):3-8. doi:10.1161/01.HYP.32.1.3.

[46] Tsukada T, Yokoyama K, Arai T, Takemoto F, Hara S, Yamada A, et al. Evidence of association of the ecNOS gene polymorphism with plasma NO metabolite levels in humans. Biochem Biophys Res Commun 1998;245(1):190-193. doi:10.1006/bbrc.1998.8267.

[47] Yoon Y, Song J, Hong SH, Kim JQ. Plasma nitric oxide concentrations and nitric oxide synthase gene polymorphisms in coronary artery disease. Clin Chem 2000;46(10):1626-1630.

[48] Jeerooburkhan N, Jones LC, Bujac S, Cooper JA, Miller GJ, Vallance $\mathrm{P}$, et al. Genetic and environmental determinants of plasma nitrogen oxides and risk of ischemic heart disease. Hypertension 2001;38(5):1054-1061. doi:10.1161/hy1101.092967.
[49] Wang XL, Mahaney MC, Sim AS, Wang J, Wang J, Blangero J, et al. Genetic contribution of the endothelial constitutive nitric oxide synthase gene to plasma nitric oxide levels. Arterioscler Thromb Vasc Biol 1997;17(11):3147-3153. doi:10.1161/01.ATV.17.11.3147.

[50] Wang XL, Sim AS, Wang MX, Murrell GA, Trudinger B, Wang J. Genotype dependent and cigarette specific effects on endothelial nitric oxide synthase gene expression and enzyme activity. FEBS Lett 2000;471(1):45-50. doi:10.1016/S0014-5793(00)01356-9.

[51] Li C, Tong W, Liu B, Zhang A, Li F. The -1082A $>$ G polymorphism in promoter region of interleukin-10 and risk of digestive cancer: a metaanalysis. Sci Rep 2014;4:5335. doi:10.1038/srep05335.

[52] Hsueh KC, Lin YJ, Chang JS, Wan L, Tsai YH, Tsai CH, et al. Association of interleukin-10 A-592C polymorphism in Taiwanese children with Kawasaki disease. J Korean Med Sci 2009;24(3):438-442. doi:10.3346/jkms.2009.24.3.438

[53] Reuss E, Fimmers R, Kruger A, Becker C, Rittner C, Hohler T. Differ ential regulation of interleukin-10 production by genetic and environmental factors-a twin study. Genes Immun 2002;3(7):407-413. doi:10.1038/sj.gene.6363920.

[54] Westendorp RG, Langermans JA, Huizinga TW, Elouali AH, Verweij $\mathrm{CL}$, Boomsma DI, et al. Genetic influence on cytokine production and fatal meningococcal disease. Lancet 1997;349(9046):170-173. doi:10.1016/S0140-6736(96)06413-6.

[55] Pan XF, Yang SJ, Loh M, Xie Y, Wen YY, Tian Z, et al. Interleukin-10 gene promoter polymorphisms and risk of gastric cancer in a Chinese population: single nucleotide and haplotype analyses. Asian Pac J Cancer Prev 2013;14(4):2577-2582.

[56] Koss K, Fanning GC, Welsh KI, Jewell DP. Interleukin-10 gene promoter polymorphism in English and Polish healthy controls. Polymerase chain reaction haplotyping using $3^{\prime}$ mismatches in forward and reverse primers. Genes Immun 2000;1(5):321-324. doi:10.1038/ sj.gene.6363669.

[57] Kube D, Platzer C, von Knethen A, Straub H, Bohlen H, Hafner M, et al. Isolation of the human interleukin 10 promoter. Characterization of the promoter activity in Burkitt's lymphoma cell lines. Cytokine 1995;7(1):1-7. doi:10.1006/cyto.1995.1001.

[58] Goyette P, Sumner JS, Milos R, Duncan AM, Rosenblatt DS, Matthews RG, et al. Human methylenetetrahydrofolate reductase: isolation of cDNA, mapping and mutation identification. Nat Genet 1994;7(2):195-200. doi:10.1038/ng0694-195.

[59] Cattaneo M. Hyperhomocysteinemia, atherosclerosis and thrombosis. Thromb Haemost 1999;81(2):165-176.

[60] Jager A, Kostense PJ, Nijpels G, Dekker JM, Heine RJ, Bouter LM, et al. Serum homocysteine levels are associated with the development of (micro)albuminuria: the Hoorn study. Arterioscler Thromb Vasc Biol 2001;21(1):74-81. doi:10.1161/01.ATV.21.1.74.

[61] Wang X, Nie SP. The coronary slow flow phenomenon: characteristics, mechanisms and implications. Cardiovasc Diagn Ther 2011;1(1):3743. doi:10.3978/j.issn.2223-3652.2011.10.01.

[62] Ridker PM, Hennekens CH, Roitman-Johnson B, Stampfer MJ, Allen J. Plasma concentration of soluble intercellular adhesion molecule 1 and risks of future myocardial infarction in apparently healthy men. Lancet 1998;351(9096):88-92. doi:10.1016/s0140-6736(97)09032 6.

[63] Inwald D, Davies EG, Klein N. Demystified...adhesion molecule deficiencies. Mol Pathol 2001;54(1):1-7. doi:10.1136/mp.54.1.1.

[64] Pare G, Ridker PM, Rose L, Barbalic M, Dupuis J, Dehghan A, et al. Genome-wide association analysis of soluble ICAM-1 concentration reveals novel associations at the NFKBIK, PNPLA3, RELA, and SH2B3 loci. PLoS Genet 2011;7(4):e1001374. doi:10.1371/journal. pgen.1001374.

[65] Bielinski SJ, Pankow JS, Li N, Hsu FC, Adar SD, Jenny NS, et al. ICAM1 and VCAM1 polymorphisms, coronary artery calcium, and circulating levels of soluble ICAM-1: the multi-ethnic study of atherosclerosis (MESA). Atherosclerosis 2008;201(2):339-344. doi:10.1016/j.atherosclerosis.2008.02.031.

[66] Tawakol A, Omland T, Gerhard M, Wu JT, Creager MA. Hyperhomocyst(e)inemia is associated with impaired endotheliumdependent vasodilation in humans. Circulation 1997;95(5):11191121. doi:10.1161/01.CIR.95.5.1119.

[67] Celermajer DS, Sorensen K, Ryalls M, Robinson J, Thomas O, Leon- 
ard JV, et al. Impaired endothelial function occurs in the systemic arteries of children with homozygous homocystinuria but not in their heterozygous parents. J Am Coll Cardiol 1993;22(3):854-858. doi:10.1016/0735-1097(93)90203-D.

[68] Loscalzo J. The oxidant stress of hyperhomocyst(e)inemia. J Clin Invest 1996;98(1):5-7. doi:10.1172/jci118776.

[69] Stampfer MJ, Malinow MR, Willett WC, Newcomer LM, Upson B, UIImann D, et al. A prospective study of plasma homocyst(e)ine and risk of myocardial infarction in US physicians. Jama 1992;268(7):877881. doi:10.1001/jama.1992.03490070059042.

[70] Ubbink JB, Vermaak WJ, van der Merwe A, Becker PJ. Vitamin B-12, vitamin B-6, and folate nutritional status in men with hyperhomocysteinemia. Am J Clin Nutr 1993;57(1):47-53.
[71] Lerman A, Holmes DR Jr, Bell MR, Garratt KN, Nishimura RA, Burnett JC Jr. Endothelin in coronary endothelial dysfunction and early atherosclerosis in humans. Circulation 1995;92(9):2426-2431. doi:10.1161/01.CIR.92.9.2426.

[72] Kaski JC, Cox ID, Crook JR, Salomone OA, Fredericks S, Hann C, et al. Differential plasma endothelin levels in subgroups of patients with angina and angiographically normal coronary arteries. Coronary Artery Disease Research Group. Am Heart J 1998;136(3):412-417. doi:10.1016/S0002-8703(98)70214-5.

[73] Dhawan J, Bray CL. Are Asian coronary arteries smaller than Caucasian? A study on angiographic coronary artery size estimation during life. Int J Cardiol 1995;49(3):267-269. doi:10.1016/01675273(95)02315-N. 